
SWPS 2017-18 (September)

Lost in Transition? Drivers and Barriers in the Eco-Innovation Road to the Circular Economy

Ana de Jesus and Sandro Mendonça

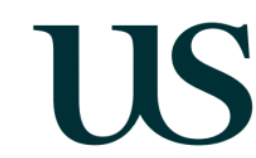




\section{SPRU Working Paper Series (ISSN 2057-6668)}

The SPRU Working Paper Series aims to accelerate the public availability of the research undertaken by SPRU-associated people, and other research that is of considerable interest within SPRU, providing access to early copies of SPRU research.

\section{Editors}

Tommaso Ciarli

Daniele Rotolo

Associate Editors
Karoline Rogge
Paul Nightingale,
Ben Martin, \&
Ohid Yaqub
Tommaso Ciarli
Joe Tidd \&
Carlos Sato
Maria Savona
Andrew Stirling
Caitriona McLeish
Editorial Assistance
Martha Bloom

\section{Contact}

T.Ciarli@sussex.ac.uk

D.Rotolo@sussex.ac.uk

\author{
Area \\ Energy \\ Science, \& Technology Policy \\ Development \\ Technology Innovation Management \\ Economics of Technological Change \\ Transitions \\ Civil Military Interface \\ K.Rogge@sussex.ac.uk \\ P.Nightingale@sussex.ac.uk \\ B.Martin@sussex.ac.uk \\ O.Yaqub@sussex.ac.uk \\ T.Ciarli@sussex.ac.uk \\ J.Tidd@sussex.ac.uk \\ C.E.Y.Sato@sussex.ac.uk \\ M.Savona@sussex.ac.uk \\ A.C.Stirling@sussex.ac.uk \\ C.A.McLeish@sussex.ac.uk
}

\section{Guidelines for authors}

Papers should be submitted to swps@sussex.ac.uk as a PDF or Word file. The first page should include: title, abstract, keywords, and authors' names and affiliations. The paper will be considered for publication by an Associate Editor, who may ask two referees to provide a light review. We aim to send referee reports within three weeks from submission. Authors may be requested to submit a revised version of the paper with a reply to the referees' comments to swps@sussex.ac.uk. The Editors make the final decision on the inclusion of the paper in the series. When submitting, the authors should indicate if the paper has already undergone peer-review (in other series, journals, or books), in which case the Editors may decide to skip the review process. Once the paper is included in the SWPS, the authors maintain the copyright.

\section{Websites}

UoS: www.sussex.ac.uk/spru/research/swps

SSRN: http://www.ssrn.com/link/SPRU-RES.html

IDEAS: ideas.repec.org/s/sru/ssewps.html

Research Gate: www.researchgate.net/journal/2057-6668_SPRU_Working_Paper_Series 


\title{
Lost in transition?
}

\section{Drivers and barriers in the Eco-innovation road to the Circular Economy}

\author{
Working Paper
}

\author{
Ana de Jesus \\ CENSE - Universidade Nova de Lisboa, Lisbon, Portugal \\ aij.silva@fct.unl.pt ,+351910187796 \\ (corresponding author)
}

and

\begin{abstract}
Sandro Mendonça
Instituto Universitário de Lisboa (ISCTE-IUL), Business Research Unit (BRU-IUL), Lisboa, Portugal, Research Unit on Complexity and Economics (UECE-ISEG), Lisboa, Portugal. Business SPRU, University of Sussex, Brighton, UK smfm@iscte.pt
\end{abstract}




\begin{abstract}
Understanding which drivers and barriers exist in the development of a Circular Economy (CE) is a relevant and timely endeavour. The aim of this paper is to contribute to this debate by analysing evidence regarding the different factors helping and hampering the development of a CE. Specifically, this paper focuses on the eco-innovation (EI) pathway towards a CE, and tries to coordinate available but fragmented findings regarding how "transformative innovation" can foster this transition while removing obstacles to sustainability. Drawing upon a new corpus of both academic and non-academic literature, this work offers a framework for analysis, as well as an evidence-based survey of the challenges, for a green structural change of the economy. We argue that the combination of the innovation systems' view with the more recent "transformation turn" in innovation studies may provide an appropriate perspective for understanding the transition to a CE. Ultimately, the paper aims to capitalise on these insights to contribute to the design of policy guidelines and organisational strategies.
\end{abstract}

Keywords: circular economy; eco-innovation; barriers; drivers; survey 


\section{Introduction}

The circular economy (CE) has emerged as a key approach in the transition to a more sustainable economic paradigm. It highlights what is to be rejected, the linear 'take-makedispose' economy, and proposes instead a “(...) system that is restorative or regenerative by intention and design" (EMF, 2012, p. 7). Furthermore, a CE is not described necessarily as a disruptive concept, but rather as a workable socio-technical approach for attaining economic and ecological sustainability. It is depicted as a framework compatible with companies' and countries' needs to reduce input costs, as well as desires to operate in a world with less unpredictability (WEF, 2014).

Creeping into academic literature since the late 1960s, but only recently entering the policy agenda, the CE is considered as a motivational and inspirational compass, a desired "end-state" (Gregson et al., 2015). The CE formally entered the realm of actual public policy in China in the Cleaner Production Promotion Law of 2002 and the subsequent Circular Economy Promotion Law of 2009 (Standing Committee of the National People's Congress - China, 2009). The concept also became the main plank of the EU Action Plan for the Circular Economy, several years later (EC, 2015a).

Identifying the determinants of this societal transition is challenging (Stirling, 2011). One reason is that a $\mathrm{CE}$ is still a rather underspecified notion, difficult to describe, and comprising diverse areas, including: sustainable production-consumption systems; closed-loop supplychains, and; product-service systems. Thus, despite its status as a transition hypothesis towards a new socio-technical regime, the $\mathrm{CE}$ is still a rather poorly understood notion. In addition, the methodologies for actually delivering a $\mathrm{CE}$ are even more blurred and uncertain. Hence, it is important to develop a thorough understanding of the factors that foster and hinder the transition to a CE. The primary goal of this paper is then to map out the drivers that promote or streamline a CE, as well as the barriers that most frequently derail it, or slow it down. A 
second, complementary, goal is to articulate more specifically what the CE concept really entails; this is done by employing the notion of systemic innovation, which is so central to modern neo-Schumpeterian studies.

Eco-innovation (EI) has been acknowledged as a particular pathway for increasing efficiency and competitiveness whilst also having positive impacts on the environment and society (EIO, 2013). EI can be used as a transformative process to move away from the status quo, to thus create a socio-economic system based on the concept of the CE. This EI transition towards a $\mathrm{CE}$ is both uneven (as some activities or sectors will change sooner than others) and destabilising (as pro-CE factors and actors will encourage others to change too). In other words, EI has the potential to trigger a chain of changes and create localised pressures, thus stimulating complementary adaptations elsewhere, which then come together to form a new technoeconomic system. As innovation enabled the development of an industrial, carbon-intensive economy, it is plausible that ("transformative") innovation may now be the vehicle for triggering a new, "green" transition (Schot and Kanger, 2016). Today, it is both topical and urgent to understand how, and by which means, innovation is able to facilitate the emergence of a CE. This paper takes an innovation studies perspective to address the challenges to the $\mathrm{CE}$, in particular by answering the following two questions: (1) What are the major drivers and barriers to a CE? (2) What is the role of EI in the transition to a CE?

Drawing on contributions from both academic and grey literature, the aim of this paper is to analyse available evidence regarding the transition towards a CE, using EI heuristics and trajectories. To structure the debate we offer an integrated and up-to-date conceptual and empirical approach to dynamic CE studies: the perspective is informed by the innovation systems view and the more recent "transformation turn" in innovation studies as we move on to assemble and make sense of a new database of relevant sources, including both academic 
papers and policy reports. These two distinct types of sources were used, in a complementary way, to take stock of progress in policy-relevant research.

The next section of this paper focuses on definitional issues regarding the CE, EI, and the drivers of, and barriers to, the CE. Section 3 then refers to the methodological framework used, and Section 4 presents the results regarding the identification of drivers and barriers to a $\mathrm{CE}$, as well as the role of EI in this transition. Finally, Section 5 presents some concluding observations, highlighting the limitations of this research, as well as possible avenues for further work.

\section{The Circular Economy and Eco Innovation under scrutiny}

\subsection{A more circular economy}

The structural socio-economic changes introduced by the Industrial Revolution and two World Wars changed the way goods were extracted, produced, delivered, consumed and discarded (Womack et al., 1990). Those changes, named the "First Deep Transition" by Schot and Kanger (2016), had severe cumulative consequences for the global environment, including climate change, degradation of ecosystems and depletion of natural capital. Even with significant environmental improvements, in developed and emerging economies alike, the prevailing global trends in manufacturing and consumption will continue to be a problem for current and future generations.

These issues have been addressed in technical and academic literature since the 1960s in diverse ways. Initial works on the "economics of the coming spaceship earth" by Boulding (1966), Georgescu-Roegen's (1971) “ecological economics" or Stahel's work on the “performance economy” (Stahel, 1982, 1986; Stahel and Reday-Mulvey, 1981) have raised 
fundamental methodological and substantive questions regarding linear economic dynamics in a context of limited availability, such as the resources of planet Earth. These intellectual traditions were brought together in a contribution by Pearce and Turner (1990) entitled Economics of Natural Resources and the Environment, particularly in the chapter titled "The circular economy". The development of other concepts, such as "industrial ecology" and "industrial symbiosis", highlighted the potential efficiency of natural ecosystems in resource recycling, thus suggesting the application of this same principle to production systems (Ayres, 1994; Frosch, 1992; Frosch and Gallopoulos, 1989).

The CE came of age in the 2000s as a synthetic concept. It encompasses diverse topics including: product-life extension activities (reuse, repair, recycling) and material efficiency (Rashid et al., 2013; Golini et al., 2014; Lund, 1985; Allwood, 2014; Lund and Skeels, 1983; Conn, 1978); product-service systems (Stahel, 1982, 1997; Tukker, 2013); sustainable consumption and production interactions (OECD, 2008); waste management and networks of recovery (Greyson, 2007; Liu, 2009; Allwood, 2014; Liu and Bai, 2014; OECD, 1982); closedloop supply chains (Gupta and Palsule-Desai, 2011; Ji et al., 2014; Mirhedayatian et al., 2014; Govindan et al., 2014; Ying and Li-jun, 2012); cleaner production (Geng et al., 2012; Li et al., 2013; Su et al., 2013); green/regenerative design (Bakker et al., 2014), and; "cradle to cradle" approaches (Braungart and McDonough, 2002). Most importantly, recent literature has presented the $\mathrm{CE}$ as an analytical template for a new mode of socio-technical organisation, where the environment and the economy are rebalanced (George et al., 2015; Ghisellini et al., 2016).

Besides its academic penetration, the $\mathrm{CE}$ has been stressed as an overall strategic framework by international organisations such as the United Nations and the European Union, as well as 
by entities such as the World Economic Forum (WEF), ${ }^{1}$ and non-governmental organisations such as the Ellen MacArthur Foundation ${ }^{2}$ (EMF). These organisations have actively produced "grey literature" highlighting the potential of a CE for creating an innovative and sustainable transition (EMF, 2012, 2013, 2014b; UNEP, 2006; EC, 2015a, 2014a).

Drawing on existing literature, the CE can, therefore, be defined as a multidimensional, dynamic, integrative approach, promoting a reformed socio-technical template for carrying out economic development, in an environmentally sustainable way, by re-matching, rebalancing and re-wiring industrial processes and consumption habits into a new usageproduction closed-loop system. The drivers of, and barriers to, such transformative reform are, therefore, of policy interest.

\subsection{Innovation for a Circular Economy}

Transition is an inherently innovation-intensive process of reconfiguration and adaptation. More than just "novelty introduction", innovation is embedded in a wider social and economic structure, rooted in a specific historical and territorial context (Freeman, 1987). The connection between environmental challenges and the innovation agenda can be traced back at least to the early 1990s. In the first Handbook on innovation economics, management and policy, some significant attention was devoted to this connection under the heading of "Future challenges of innovation in a global perspective" (see Skea, 1994). More than two decades later, however, relevant literature, linking innovation and the environment, has still not been sufficiently

\footnotetext{
${ }^{1}$ In a report of 2014 entitled Towards the Circular Economy, developed in collaboration with the Ellen MacArthur Foundation and McKinsey \& Company, the WEF stressed the need to re-engineer global supply chains and regenerate natural assets.

2 The EMF initiated, for example, the "Circular Economy 100" programme to enable cooperation between companies (e.g. Desso, Michelin, Philips International, Unilever, Renault, Ricoh, Veolia, H\&M, Nespresso among several others), regions (Danish Business Authority) and universities (University College London), and to assist in the development of circular commercial opportunities (EMF, 2014a).
} 
developed. In a recent editorial in the Journal of Economic Surveys, in the context of a special issue concerning "Environmental economics and sustainability", the organisers, two scholars from Chinese universities who specialise in institutional economics and urban development, attempt to summarise the research agenda:

“(...) environmental technological innovation may potentially lead to win-win situations in which improvements in environmental quality and economic growth coexist." (Lin and Zheng, 2016, p. 400).

In the field of innovation studies there are several approaches related to transition and sustainability. In the context of this paper, "eco-innovation" (EI) will be used as an operative definition of innovation with ecological and social concerns and effects (Boons et al., 2013; Carrillo-Hermosilla et al., 2009; Kunapatarawong and Martínez-Ros, 2016; Rennings, 2000). EI is understood as more than just green technology (i.e. devices that provide environmentally beneficial effects, such as end-of-line interventions - e.g. fume exhaust catalysers), but rather as a strategic enabler of entire value-chain transformations (Andersen, 2008; Kemp, 2010). As Clark et al (2016) point out, a full notion of innovation under sustainability constraints implies recirculation of resources in loops of reuse (through refurbishment and re-manufacturing), recycling (reconstructing inputs and reshaping outputs) and renewal (using clean energy and eliminating waste). Such pathways can even have a positive effect on employment (Kunapatarawong and Martínez-Ros, 2016). EI that is pro-CE thereby improves “(...) environmental performance and resilience across the economy, being at the same time costeffective and good for business and society as a whole.” (EC, 2011, p. 3).

For the purposes of this paper the following definition of EI is used: new or improved sociotechnical solutions that preserve resources, mitigate environmental degradation and/or allow recovery of value from substances already in use in the economy. EI is understood as a systemic problem-solving tool for enabling a holistic and transformative departure from the current unsustainable state-of-play. By combining the neo-Schumpeterian systems view with the 
emerging "transformation turn" in innovation studies we aim to bring an explicit (dynamic) conceptual backdrop to the discussion of CE.

\subsection{Focusing on the drivers of, and barriers to, a Circular Economy}

Considerable research exists regarding progress towards a $\mathrm{CE}$ in countries, sectors and firms (Böttcher and Müller, 2013; Cuerva et al., 2014; Geng et al., 2009; Ilić and Nikolić, 2016; Zhu and Geng, 2013). Specifically concerning barriers to implementing the CE, a report for Chatham House (Preston, 2012) identified the following: high up-front costs; complex international supply chains; resource-intensive infrastructure lock-in; failures in company cooperation; lack of consumer enthusiasm, and; limited dissemination of innovation, across both emerging economies and developed countries. In other reports, concerning the potential of the CE, and policy options, Vanner et al. (2014) surveyed the available literature and analysed the fourteen most relevant studies. They identified a number of factors: insufficient investment in technology; economic signals that do not encourage efficient resource use, pollution mitigation or innovation; minor consumer and business acceptance; lack of awareness and information, and; limited sustainable public incentives. Concerning the CE in SME's, Rizos et al. (2015) also used a literature review ${ }^{3}$ and explored two case studies. ${ }^{4} \mathrm{He}$ listed six main barriers for the development of a CE, namely: environmental culture; financial barriers; limited government support; lack of effective legislation; information deficits; administrative burdens, and; relatively low technical skills.

In spite of increasing efforts, there is still a need for a thorough identification of the conditions required for a CE, especially when the concept intersects with EI (EIO, 2016). To advance the

\footnotetext{
${ }^{3}$ It lacks information, however, regarding the methodological choices in the identification of that literature.

${ }^{4}$ Also unclear are the motivations regarding the choice of two particular cases from a pool of 52 collected by the EU-funded project The GreenEcoNet.
} 
research agenda on the $\mathrm{CE}$, this paper carries out a systematic exploration of both drivers and barriers, recycling multiple sources of literature input. Likewise, an innovation perspective on CE mechanisms is advanced, by analysing the role of technological and non-technological factors in the creation of a new, circular, techno-economic paradigm. Such a diagnosis can support policy-making, by moving beyond the linear-industrial model.

Innovation is a splintered phenomenon. As Stoneman (2009, 2010) points out, economics typically focuses on hard types of innovation, such as R\&D-driven products, or cost-cutting processes. Yet soft types of innovation, concerned with changes in cultural and organisational artefacts, such as symbols and conventions, are more widespread than previously thought (see Mendonça, 2014). The International Relations scholar Joseph Nye (1990, 2006) has applied such hard/soft heuristics (probably deriving such terminology from the hardware/software distinction). In this context, hard power refers to the ability to force change (through technical or economic means) while soft power is associated with the ability to bring about change by attracting others through values and institutional practices that shape their attitudes and preferences. This conceptualisation may, indeed, be applied to innovation-related factors steering the current system in the direction of another, more sustainable one. Notwithstanding their complementary nature, and the obvious fact that they are not always easy to separate in practice, we apply the hard-soft dichotomy to the CE transition.

Table 1 applies this view as a "focusing device" for organising the relevant literature at the CEEI intersection. It distinguishes between "harder" factors, more closely related to technoeconomic trajectories, and "softer" ones, having to do with regulatory and cultural issues.

\begin{tabular}{l|c|c|}
\multirow{2}{*}{ Technical and economic factors } & Drivers & Barriers \\
\cline { 2 - 3 } & Hard drivers & Hard barriers \\
\hline Institutional and social factors & Soft drivers & Soft barriers \\
\cline { 2 - 3 } & &
\end{tabular}

Table 1 - Factors facilitating and constraining the transition towards a CE 
Based on existing literature, several broad factors driving and preventing the CE were identified in the corpus, in an iterative process, ranging from arguably the "hardest" (technical, economic) to the "softest" (social, institutional) factors (Table 2). The "drivers" are therefore factors that enable and encourage the transition to a CE, while the "barriers" are technical/financial impediments or regulatory/cultural bottlenecks that obstruct transitions towards a CE (Table 2). Typically, there is not just one important driver or barrier, but rather a mixture of facilitating and constraining factors, deriving from particular local conditions. The categories, therefore, should not be understood as mutually exclusive.

\section{Drivers}

Barriers

\begin{tabular}{|c|c|c|c|}
\hline$\frac{\sqrt{5}}{\sqrt[0]{5}}$ & Technical & $\begin{array}{l}\text { availability of technologies that facilitate resource } \\
\text { optimisation, re-manufacturing and re-generation } \\
\text { of by-products as input to other processes, } \\
\text { development of sharing solutions with superior } \\
\text { consumer experience and convenience }\end{array}$ & $\begin{array}{l}\text { inappropriate technology, lag between design and } \\
\text { diffusion, lack of technical support and training }\end{array}$ \\
\hline 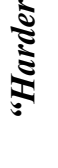 & $\begin{array}{l}\text { Economic/ } \\
\text { Financial/ } \\
\text { Market }\end{array}$ & $\begin{array}{l}\text { related to demand-side trends (rising resource } \\
\text { demand and consequent pressures resource } \\
\text { depletion) and supply-side trends (resource cost } \\
\text { increases and volatility, leading to incentives } \\
\text { toward solutions for cost reduction and stability) }\end{array}$ & $\begin{array}{l}\text { large capital requirements, significant transaction } \\
\text { costs, high initial costs, asymmetric information, } \\
\text { uncertain return and profit }\end{array}$ \\
\hline$\frac{2}{8}$ & $\begin{array}{l}\text { Institutional/ } \\
\text { Regulatory }\end{array}$ & $\begin{array}{l}\text { associated with increasing environmental } \\
\text { legislation, environmental standards and waste } \\
\text { management directives }\end{array}$ & $\begin{array}{l}\text { misaligned incentives, lacking of a conducive legal } \\
\text { system, deficient institutional framework }\end{array}$ \\
\hline$\underbrace{\infty}_{0}$ & $\begin{array}{c}\text { Social/ } \\
\text { Cultural }\end{array}$ & $\begin{array}{l}\text { connected to social awareness, environmental } \\
\text { literacy and shifting consumer preferences (e.g. } \\
\text { from ownership of assets to services models) }\end{array}$ & $\begin{array}{l}\text { rigidity of consumer behaviour and businesses } \\
\text { routines }\end{array}$ \\
\hline
\end{tabular}

Table 2 - Typology and definition of drivers of, and barriers to, a CE

From an analytical point of view, such a framework allows for an appreciation of both the dynamics and the inertia of the CE. From a policy point of view, the framework may be of service to tackle policy-managerial dilemmas. Thus, this analytical and strategic tool clarifies the conceptual issues involved, while addressing the need to re-discover the non-technological meanings of innovation (see Hobson and Lynch, 2016; and Wildschut, 2017) laying ground towards new, imaginative, working paths ahead (see Lowy and Hood, 2004, Granjou et al., 2017). 


\section{Methodological approach}

\subsection{Research design: Scope and strategy of study}

This review uses a dual approach as to minimise biases that would be present if only a single one was in place. That is, it draws on both a corpus of articles from WoS and Scopus and a set of contrasting examples of grey literature. Both academic literature and policy reports are used so as to make the study more complete, balanced, robust and meaningful. Figure 1 presents the layout of the research.

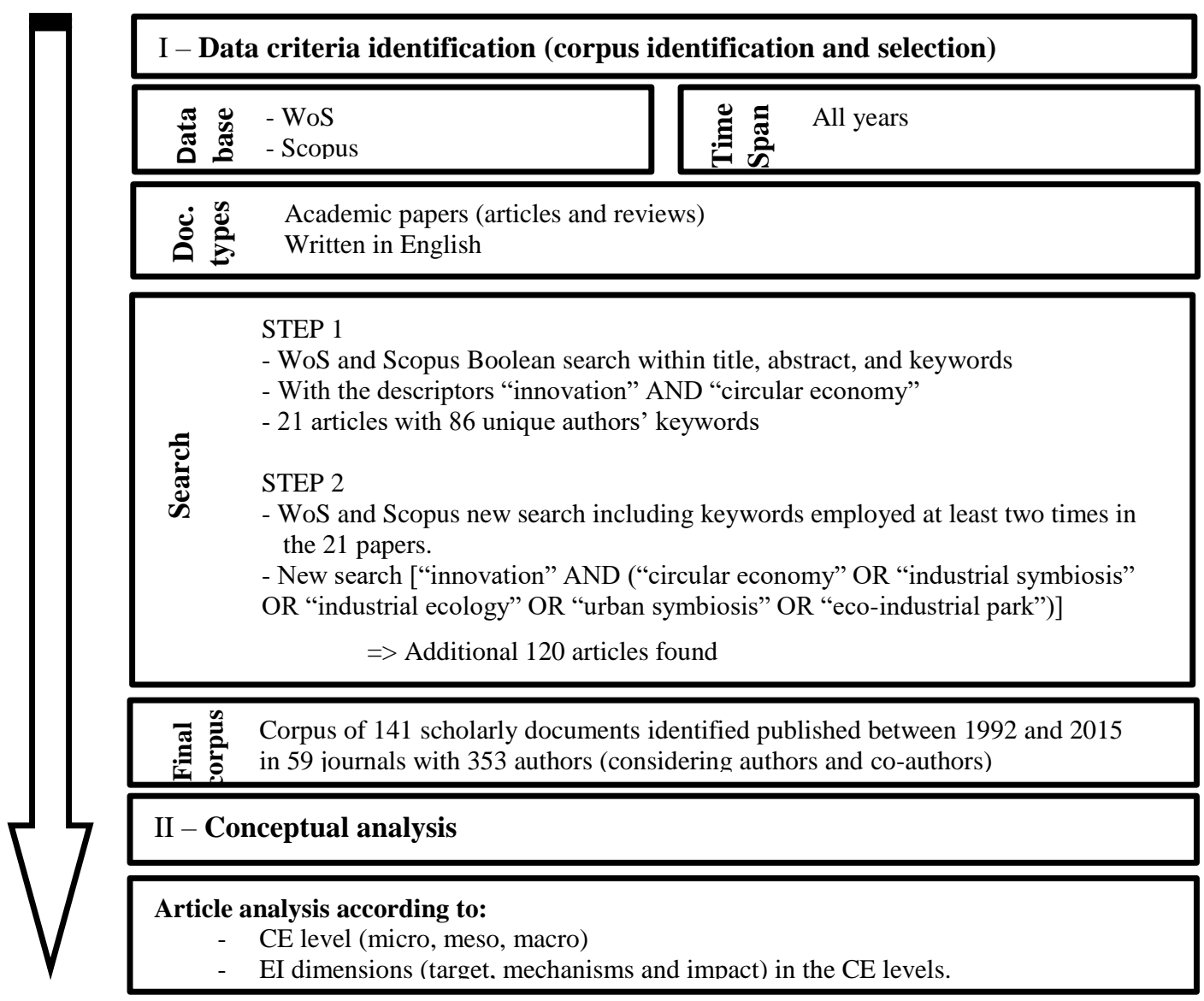

Figure 1 - Research design

\subsection{The CE-EI nexus in the academic corpus: Some descriptive statistics}

A systematic review enables the analysis of the evolution of the knowledge regarding a specific topic, as well as the identification of trends and changes in a research field (Linnenluecke and Griffiths, 2013). Such an approach to the literature, guided by specific research questions, and 
using explicit protocols and criteria, has the added value of ensuring the replicability of the process, thus contributing to much needed cumulative work in this field (Patala et al., 2014).

The study therefore began by gathering data using a keyword Boolean search of articles in the Web of Science (WoS) Core Collection and in Scopus. These two databases have long-term worldwide coverage, including the largest number of peer-reviewed journals, and work best in combination (Chappin and Ligtvoet, 2014). Although, arguably closer to the research frontier, conference proceedings have a less systematic coverage, and a limited availability of sources (on the difficulties regarding these materials, see Michels and $\mathrm{Fu}, 2014$ ). Therefore, only peerreviewed "finished" articles in indexed academic journals were included (professional journals were also left out).

In the first phase, the search used only the descriptors "innovation" and "circular economy". 5 This identified 21 articles. A second search was then conducted, using authors' keywords that had been employed at least twice in these 21 articles. Based on this set of new descriptors ${ }^{6}$, a total of 141 papers were then identified. The articles were then read in full, focusing on the consideration of drivers of, and barriers to, the $\mathrm{CE}$, as well as the role of EI in the development of the CE.

The final corpus covers a time span between 1992 and 2015. The number of relevant research articles appears to have grown considerably in the second half of the 2000's (Figure 2), with the most recent years providing the highest number of publications (20 papers).

\footnotetext{
5 ("innovat*”AND ("circular economy" OR “circular-economy” OR “circul* economy*”)

6 ("industrial symbiosis”, "industrial ecology”, "urban symbiosis” and "eco-industrial park”)
} 


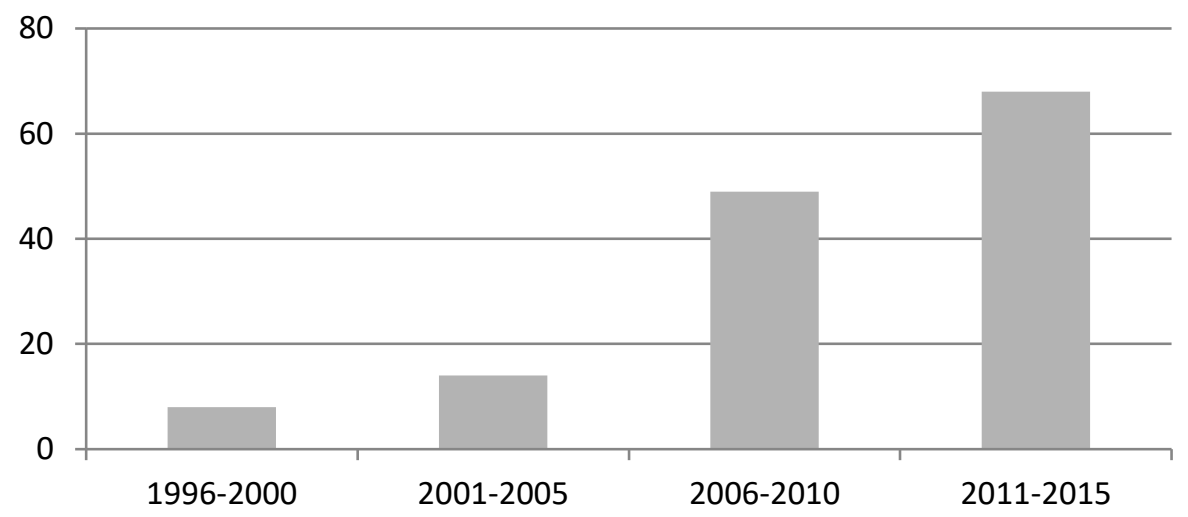

Figure 2 - Number of CE-EI articles per five year period

Note: Elaborations on Scopus and WoS

The articles came from 59 journals. The top five journals are revealing (Table 3). They make up more than half $(54.5 \%)$ of the corpus, and focus on engineering and environmental sciences, as well as governmental policies and strategies for addressing these challenges.

\begin{tabular}{l|l|l}
\hline Journals & Focus of the journal & $\begin{array}{l}\text { Share of total } \\
\text { articles in corpus }\end{array}$ \\
\hline $\begin{array}{l}\text { Industrial Ecology } \\
\text { Ind of }\end{array}$ & $\begin{array}{l}\text { Journal dedicated to the study of the field of industrial } \\
\text { the challenges of environmental problems. Focuses on } \\
\text { research on product life-cycles, including extraction, } \\
\text { production, use and waste management. }\end{array}$ & $25.5 \%$ \\
\hline $\begin{array}{l}\text { Journal of Cleaner } \\
\text { Production }\end{array}$ & $\begin{array}{l}\text { Transdisciplinary research focusing on the adoption of } \\
\text { cleaner production and sustainability developed by } \\
\text { industries, governments and universities. Its research } \\
\text { scope covers: innovation and creativity; the } \\
\text { implementation of new, cleaner structures and; the } \\
\text { implementation of prevention oriented governmental } \\
\text { policies. }\end{array}$ & $19.9 \%$ \\
\hline $\begin{array}{l}\text { Journal of } \\
\text { Mnvironmental }\end{array}$ & $\begin{array}{l}\text { Focuses on research on aspects of environmental } \\
\text { management and environmental problems. }\end{array}$ & $3.5 \%$ \\
$\begin{array}{l}\text { International } \\
\text { Sournal of } \\
\text { Sustainable } \\
\text { Development and }\end{array}$ & $\begin{array}{l}\text { Focuses on research on sustainable development. This is } \\
\text { an interdisciplinary journal, covering research on } \\
\text { environmental sustainability, economic sustainability, } \\
\text { and/or social and cultural sustainability. }\end{array}$ & $2.8 \%$ \\
\hline $\begin{array}{l}\text { Minerals } \\
\text { Engineering }\end{array}$ & $\begin{array}{l}\text { Focuses on mineral processing and extractive metallurgy } \\
\text { research, with good coverage of sustainable development } \\
\text { research. }\end{array}$ & $2.8 \%$ \\
\hline
\end{tabular}

Table 3 - Top five journals where most articles were published.

Note: Descriptions are taken from the journals' blurb and publishers' websites.

Overall, the articles are very broad in terms of thematic range. For example, the two first articles in the corpus were published by Davelaar and Nijkamp (1992) and by Ausubel (1992). 
The first paper empirically analysed the Dutch manufacturing sector from the viewpoint of urban symbiosis, questioning whether a causal relationship exists between spatial localisation and the innovation potential of these firms. The second paper, on the other hand, refers to the insights gathered during the Colloquium on Industrial Ecology held in 1991, and thus provides an overview of this discipline. These two early, and very different, articles show that diversity existed from the outset. However, they also articulate an already maturing discussion, regarding new holistic economic strategies and the potential for closing economic loops.

\subsection{Grey corpus: The structure of the sample}

As organisational and industrial practice can, in some cases, be ahead of academia in exploring new concepts, it seems prudent to put the academic corpus into perspective with the help of a different source. The tactic here is to use "grey literature", i.e. technical contributions not published as papers validated by normal scholarly procedures, but still professional and research-based. This includes reports and policy papers made by government organisations, "think tank" institutions and private companies (Schöpfel, 2010). Such grey works act, firstly, as a type of "control sample" for the academic literature. Secondly, they are also useful as examples of engaged discourse, oriented towards translating academic ideas into policy approaches and agendas.

The grey literature consists of over 40 works published between 2006 and $2015^{7}$ that generally discuss the $\mathrm{CE}$ and/or EI concepts. The reports come from prominent actors, such as the United Nations Environment Programme (UNEP), the United Nations Department of Economic and Social Affairs (UNDESA), the World Economic Forum (WEF), the European Commission

\footnotetext{
7 To facilitate the search (conducted online) the target period, ranging from 2006 to 2015, was chosen as this decade had been previously identified in the academic literature as the most prolific regarding these topics.
} 
(EC), the Eco-Innovation Observatory (EIO), the Organisation for Economic Co-operation and Development (OECD), the Ellen MacArthur Foundation (EMF), and several other institutions and enterprises.

The identification criteria of the grey sample included reports mentioned in the academic literature (which, for example, identified quite a few EU-related publications). From these initial sources, other reports were then identified through a "snowball" method, using the references in the previously identified publications. This was followed by a wide search on the internet for publications in two languages (English and French), after which another snowball procedure was carried out. The final corpus of grey publications included reports, website published texts and press releases, totalling 43 publications, from 21 different organisations. The number of publications increased substantially in the 2010s, whilst those addressing both EI and the CE also increased during this period (Figure 3).

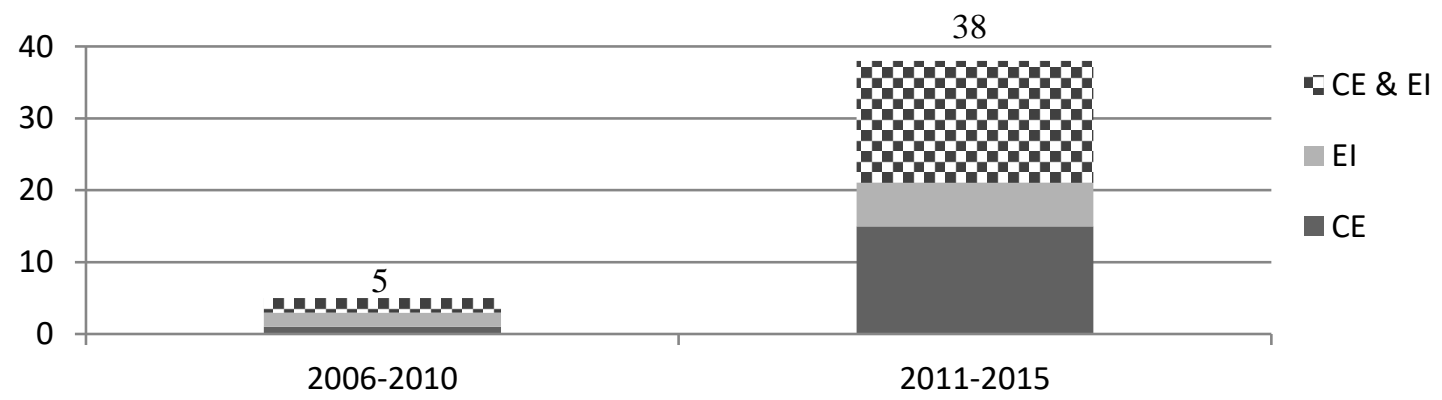

Figure 3 - Growth of grey literature mentioning the CE, EI and both concepts together, in the periods between Note: $n=43$ 2006-2010 and 2011-2016.

Almost all the publications mention innovation, as well as innovation's role in overcoming economic and social problems. Nevertheless, an explicit environmental concern is not always apparent. ${ }^{8}$ The publications that address both the CE and EI comprise $44 \%$ of the sample, but cluster only in the years 2014 and 2015 . The publications addressing both concepts scarcely

\footnotetext{
${ }^{8}$ Therefore, only when environmental or sustainability-concerned innovation was identified were the publications categorised as mentioning EI.
} 
quote academic sources, and instead cite previous EU reports or communications, and, especially, Ellen MacArthur Foundation reports. ${ }^{9}$

\subsection{What is being studied by academia and institutional actors: Comparisons and contrasts}

As expected, both types of literature have complementarities (summary in Table 4). The extraction of information from multiple types of documents and sources, resulting from different perspectives and agendas, was sought so as to ensure a methodologically robust study.

\begin{tabular}{|c|c|c|}
\hline & Academic literature & Grey literature \\
\hline Time span & $1992-2015$ & $2006-2015$ \\
\hline Focus & $\begin{array}{l}\text { - Engineering solutions } \\
\text { - Environmental studies }\end{array}$ & $\begin{array}{l}\text { - Economic benefits and costs } \\
\text { - Social sciences }\end{array}$ \\
\hline Geography & - Cases identified around the world & - More focused in developed countries cases \\
\hline Target audiences & $\begin{array}{l}\text { - Academic } \\
\text { - Governmental agents }\end{array}$ & $\begin{array}{l}\text { - Governmental agencies } \\
\text { - Enterprises }\end{array}$ \\
\hline Outcome & $\begin{array}{l}\text { Adding to the available knowledge- } \\
\text { base on the CE } \\
\text { - Recommendations or guidelines for } \\
\text { the public policies }\end{array}$ & $\begin{array}{l}\text { - Promote enterprise achievements and case } \\
\text { studies } \\
\text { - Recommendations or guidelines for the public } \\
\text { policies }\end{array}$ \\
\hline
\end{tabular}

Table 4 - Complementarities between the two sources of literature on CE and EI

The geographical origin of the CE phenomenon examined in the two bodies of literature is also useful for building a picture of the global distribution of the concept's practical application. The country of origin of each relevant CE example ${ }^{10}$ within the literature sources was recorded. Each article/report, from both the academic and grey literature, cited several CE examples from different countries, and a total of 33 nations where covered across all the sources. Figure 4 shows the countries locations where examples of CE where identified (red for the academic examples, and blue for the grey literature examples). Each circle represents the country capital,

\footnotetext{
${ }^{9}$ Highlighting the autonomy of the "grey sample" there are only two cited papers from our academic corpus, Lombardi and Laybourn (2012) and Paquin and Howard-Grenville (2012) in the report to the EU by Vanner et al. (2014).

${ }^{10}$ When recorded as "relevant" it is considered that the example was actually described and not only mentioned, including the institution/enterprise developing it, as well as the location.
} 
and its relative size indicates the number of examples cited from that country. The rising role of China is prominent: its government appears actively involved in CE implementation; and the academic corpus includes several examples of Chinese CE activities, typically as a topdown political objective for economic development. Europe, Japan, Canada, Australia and the US also show developments in CE, although with a different perspective, as it is considered more as a bottom-up tool in the definition of environmental policies (Ghisellini et al., 2016).

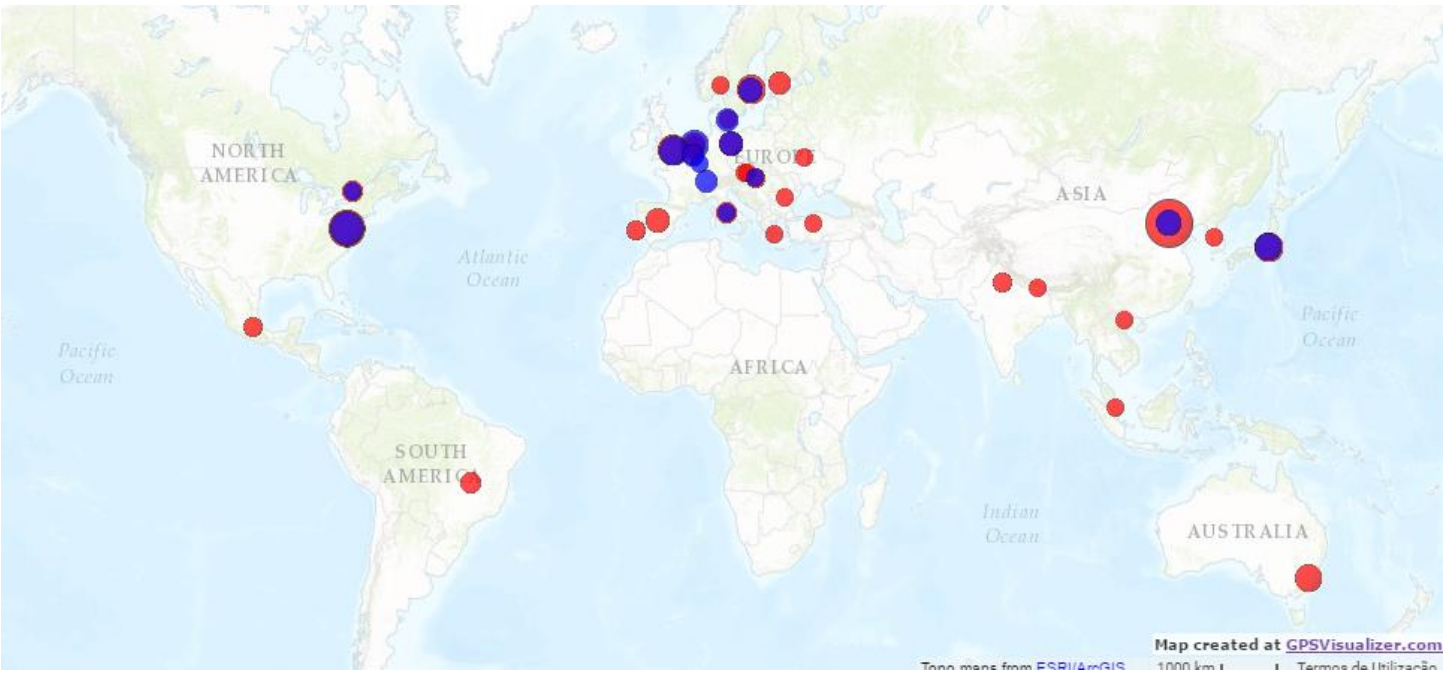

Figure 4 - Global distribution of CE examples mentioned in the academic (red) and institutional (blue) literature (colour reproduction on the web)

Source - elaborations on the academic and grey corpus

Note - The number of times a country was mentioned, and the coordinates of its capital city, were entered into gpsvisualizer.com in order to generate the map. Each circle represents a country, focusing on the capital city. The relative size of the circle represents the number of times an example in that country was mentioned.

Re-aggregating the collected data, per continent, ${ }^{11}$ it is possible to observe the differences between the two types of literature (Table 5). In the academic papers, Europe accounts for most examples, and this is even more the case in the grey literature, possibly indicating the source of research funds, as well as the demand for solutions. The grey literature seems generally more focused on examples from economically developed countries, which contrasts with the academic literature, where more examples from emerging economies, such as Brazil, Mexico and India, can be found. Examples from Africa are conspicuously absent.

\footnotetext{
${ }^{11}$ Using the UN M49 composition of macro geographical (continental) regions (UN Statistics division, 2013).
} 


\begin{tabular}{l|cc|}
\hline Europe & the academic literature & grey literature \\
Asia & $45 \%$ & $68 \%$ \\
Northern America & $30 \%$ & $17 \%$ \\
Oceania & $15 \%$ & $16 \%$ \\
Latin America and the Caribbean & $6 \%$ & $0 \%$ \\
Africa & $4 \%$ & $0 \%$ \\
\end{tabular}

Table 5 - CE global dispersion per continent Source - elaborations on the corpus

\section{Circular economy and eco-innovativeness: Boom versus doom}

\subsection{Enabling and constraining factors in the EI-led transition to a $\mathrm{CE}$}

This section analyses the transition to a CE from the perspective of innovation and inertia. The analysis begins with the research papers, which are then complemented by inputs from the grey literature later on in each subsection.. Some interesting patterns emerge. As Figure 5 suggests, taken together, softer CE drivers appear to be the factors most referred to in the academic literature. Institutional and regulatory drivers seem to be the single most present type of CE drivers among scholarly papers, which seems to point to the potential entrepreneurial role of policy in this field, as well as the role of corporate middle management. Figure 6 addresses the issues of barriers and shows that harder factors are paramount. Technical bottlenecks stand out as the perceived source of the greatest challenges. It is worth further examining these initial findings, as they reinforce the relevance of a systems view in this field. 

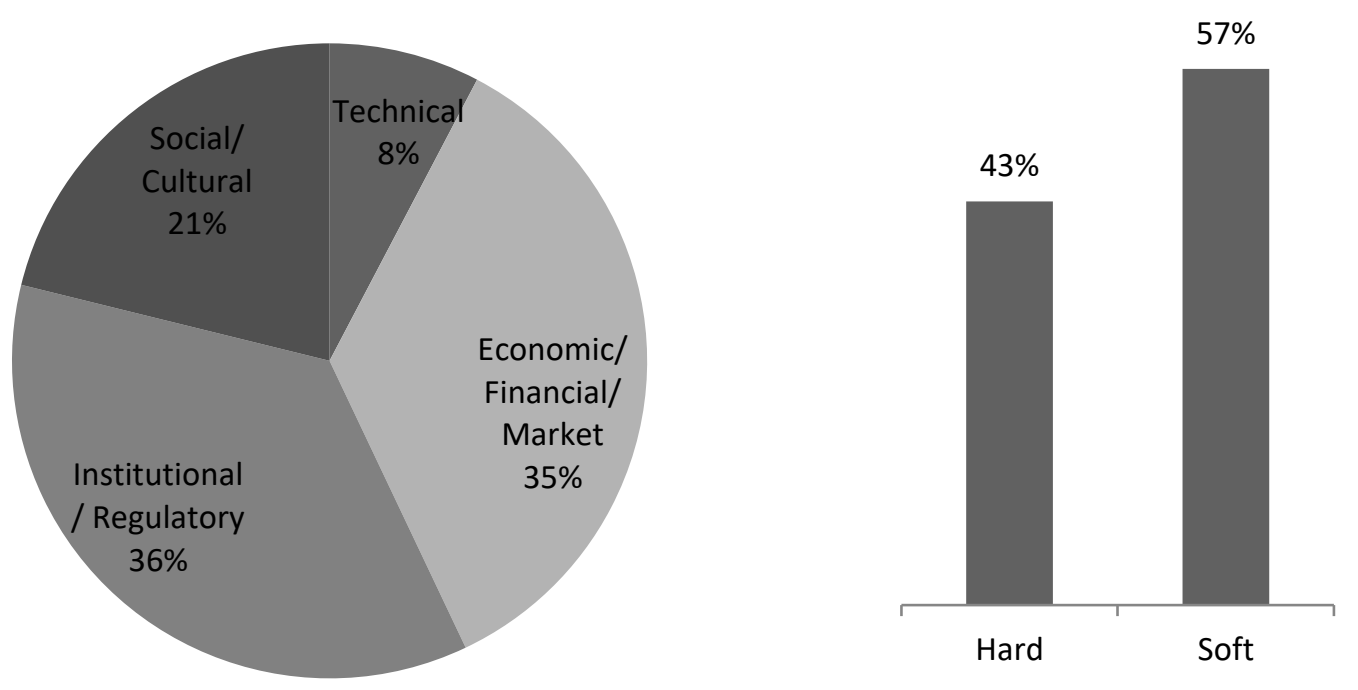

Figure 5 - Most mentioned CE drivers in the academic literature Note: $n=141$
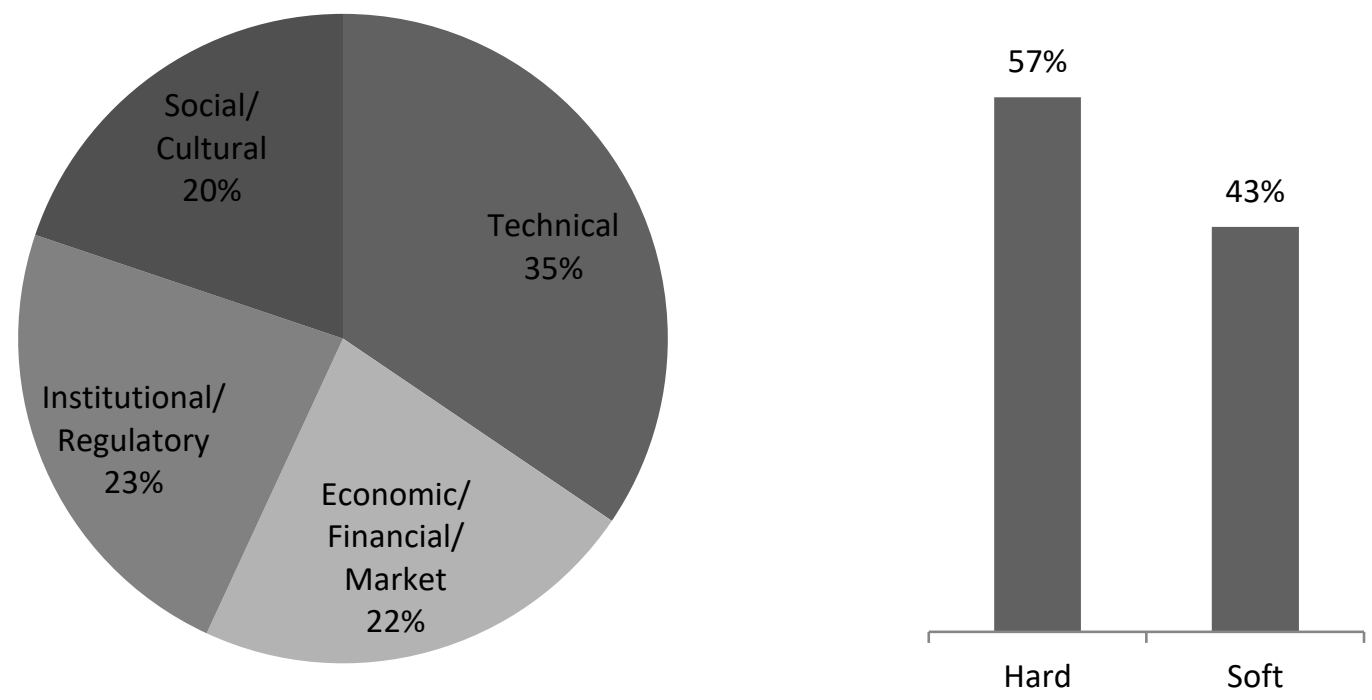

Figure 6 - Most mentioned CE barriers in the academic literature Note: $n=141$

\section{Hard drivers and barriers}

\section{Technical factors}

Moving towards a new mode of sectoral organisation, and new business templates, inevitably has profound social and economic implications. However, it is also dependent on technical knowledge, as: “(...) how we make things dictates not only how we work but what we buy, how we think, and the way we live." (Womack et al., 1990, p. 11). Changes are often perceived 
as triggered by the rise of new technologies: the steam engine impelled the industrial revolution; and, the development of computers, digital communication and microchips launched the $20^{\text {th }}$ century information revolution (Johnson and Suskewicz, 2009). In the same way, technical capacities are now fundamental in the transition to a CE.

The availability of technical solutions is an essential condition for balancing product durability, efficiency, and quality, as well as for designing optimal product life-cycle scenarios for new products and processes (for example, products intended to be rented and restored numerous times require in-depth knowledge about ongoing enhancements and the optimisation of part replacement). ${ }^{12}$ In product life extension “(...) what determines the 'possibility' of reuse for a material is the extent of knowledge that has led to technological innovation for reuse. (...) The reuse potential increases as technological options increase, enabling more material recovery." 13 In recycling and waste management, the use of by-products as inputs for other processes/products is also dependent on technical capacities. ${ }^{14}$ Likewise, the availability of information and communications technologies (ICTs) is considered a facilitator in the dematerialisation of the economy. ${ }^{15}$ A CE seems, therefore, to be dependent on a broad array of technologies in order for it to gain widespread penetration.

As the availability of technical solutions is a condition for adaptability, and thus the development of a $\mathrm{CE}$, technological challenges are considered to be a key barrier to transition (Figure 5 and 6). Technical barriers include not only factors concerning the existence of appropriate technology (technological thresholds), ${ }^{16}$ but also technology gaps (such as the lag

\footnotetext{
12 (Bakker et al., 2014; Mont, 2008). To enable an easier reading, and to distinguish the two types of literature, the academic corpus's references are gathered in footnotes.

13 (Park and Chertow, 2014, p. 47).

14 (Riding et al., 2015; Wen et al., 2007; Yu et al., 2015).

15 (Dewick et al., 2007).

16 (Geng et al., 2014; Yu et al., 2014a).
} 
between processes and product development, and the lag between invention and production), ${ }^{17}$ and the lack of sufficiently educated/specialised personnel. ${ }^{18}$

These barriers are not only stressed by the academic, but also by the grey, literature (EMF, 2012, 2013, 2015a; Vanner et al., 2014; WEF, 2014). The latter also adds warnings regarding the fact that "enormous technical hurdles need to be surmounted to accelerate innovation and ensure widespread application of resource efficient and waste-reducing technologies, especially those related to energy." (UNDESA, 2011, p. 19).

Overall, and despite available technical solutions, even more technological innovation seems to be needed to enable a CE. Moreover, existing solutions are only very slowly entering the market, due to barriers linked to investment deterrents and market problems. It is not only science and technology that need to be "re-wired": organisational and marketing assets also need holistic innovation.

\section{Economic/Financial/Market factors}

Even though, in some cases, technical solutions are already "out there", they often have limited practical application due to economic and market limitations (Figure 6). Obstacles, such as high initial costs and market uncertainty, limit new investments. ${ }^{19}$ Moreover, prevailing sociotechnical systems are often characterised by inertia and lock-ins, aggravated by strong pathdependencies that are difficult to overcome. ${ }^{20}$ For instance, regarding eco-industrial parks in China, Zhu et al. (2015, p. 459) emphasise that “(...) conflicts with financial gains, lack of a

\footnotetext{
17 (Gao et al., 2006; Kaenzig and Wüstenhagen, 2010; Pajunen et al., 2013; Vernay et al., 2013; Watkins et al., 2013).

18 “(...) lack of technical support and training (...).” (Geng et al., 2010b, p. 1506).

19 (Jones et al., 2013; Matus et al., 2012; Reh, 2013; Sanyé-Mengual et al., 2014).

20 (Markard et al., 2012).
} 
technical workforce, and lack of research funding are all barriers within China for promoting sustainable industrial development." New ways of overcoming financial barriers, arising from high upfront investment costs, emphasise the need for new financial tools, i.e. green financial innovation. ${ }^{21}$ In addition, it should be noted that SMEs have particular difficulties in financing the innovation involved in the transition to a $\mathrm{CE} .^{22}$

Economic, financial, and market drivers are, nonetheless, important factors for powering the transition to a CE (Figure 5). As resource consumption, dependence, depletion and volatility continue to rise, the need to decouple revenues from material input, and to improve resource performance, is an important incentive that encourages enterprises and industries to generate new solutions. ${ }^{23}$ Drivers stemming from the marketplace "can motivate manufacturers to initiate their sustainable purchasing efforts". ${ }^{24}$ They can also change perceptions of the environment, from a source of costs, to something much more positive, ripe with business opportunities. $^{25}$

The grey literature emphasises the importance of economic drivers. Current trends related to price volatility and increasing resource consumption ${ }^{26}$ are stressed as promoters of new, more sustainable and circular, economic models (Preston, 2012). As for barriers, the grey literature underlines market failures, namely imperfect information, and investment costs (EMF, 2015a). Financial barriers, related to the cost of developing and implementing innovation, as well as the difficulty in overcoming linear economic lock-ins, are significant, constraining the adoption

\footnotetext{
21 (Mathews and Tan, 2011).

22 (Geng et al., 2010b).

23 (Geng et al., 2010b, 2014).

24 (Zhu and Geng, 2013, p. 11).

25 (Jones et al., 2013; Maurizio Catulli, 2012; Sanyé-Mengual et al., 2014).

${ }^{26}$ These amounted to around 65 billion tonnes of raw materials in 2010 , with estimations pointing to 82 billion tonnes by 2020 (EMF, 2012).
} 
of new circular business models, especially in countries with financing difficulties and many small enterprises (Rizos et al., 2015).

\section{Soft drivers and barriers}

\section{Institutional/Regulatory factors}

In the academic corpus, "soft" institutional and regulatory drivers are extensively named as factors facilitating a CE (Figure 5). The emphasis is on public policy measures (e.g. legal frameworks, taxes, incentives, infrastructure development) addressing market failures, as well as the establishment of a conducive environment for innovation and entrepreneurship. Government is considered to play a leading role in promoting an institutional framework ${ }^{27}$ “(...) by reforming existing laws, enacting new regulations, promoting the application of new environmental technologies, and organising public education." ${ }^{28}$ The importance of institutional/regulatory drivers in the implementation of a CE is analogous to the role of laws and taxes in boosting environmental-friendly technical change (Porter and Linde, 1995). That is, policy can have a double role: it modulates behaviour in a dynamic way, since its effects are not so much direct as they are indirect, i.e. by triggering reactions that are desired in themselves. In spite of its role as a driver of change, institutional/regulatory barriers are also one of the most important factors limiting the development of a CE. An "optimal" mix of taxes, rules, infrastructures and educational set-ups promotes the CE. At the same time non-conducive legal systems and misaligned incentives are not only hurdles, but also contribute to making the incumbent paradigm more entrenched. For example, existing environmental policies influence

\footnotetext{
27 (Andrews and deVault, 2009; Bergquist et al., 2013; Carrillo-Hermosilla et al., 2010; del Río et al., 2010; Eckelman and Chertow, 2009; EMF, 2012, 2015b; Gao et al., 2006; Geng et al., 2012; Heyes and Kapur, 2011; Huesemann and Huesemann, 2007; Köhler et al., 2011; Levänen, 2015; Maurizio Catulli, 2012; Naveh, 1998; Nguyen and Ye, 2015; Pajunen et al., 2013; Subhadra, 2011; Tong and Yan, 2013; Vivanco et al., 2014; Watkins et al., 2013, 2013).

28 (Geng et al., 2009, p. 233).
} 
the definition as to what is, and what is not, waste (i.e. materials are often categorised as waste too quickly even if they, or their components, could still be reused), thus possibly hampering the development of industrial eco-parks and symbiotic relations. ${ }^{29}$ Another example of conflicting policies is the promotion of product efficiency and, at the same time, the replacement of old appliances, which sometimes carries the risk of overshooting, i.e. overinvestment in new infrastructure that utilises more resources in its construction than it will ever save over its lifetime. ${ }^{30}$ The enforcement of environmental regulations is another issue, as it is considerably more difficult to enforce than to promote laws. ${ }^{31}$

Adequate promotion and support of $\mathrm{R} \& \mathrm{D}$, education and training, so as to increase general awareness and create the required skill base, is another necessary condition of the CE. In China, for example, public education on sustainable development is considered to be insufficient, resulting in too little public involvement in environmental protection. ${ }^{32}$ Similarly, the contents of the CE are still poorly covered in university curricula, and training courses for improving industry's capacity in this area are rare. ${ }^{33}$ Addressing this issue thus can also help to reduce barriers related to technical feasibility.

The role of policies and regulations in the establishment of a CE is also emphasised in the grey literature. As the $\mathrm{CE}$ discourse entered political and business agendas, an institutional and legislative framing of such initiatives emerged (Vanner et al., 2014). The political discourse stresses that a CE “(...) requires dedicated public policies and new forms of cooperation between enterprises and public actors." ${ }^{34}$ (IAU, 2013, p. 16) In this respect, governments' role,

\footnotetext{
${ }^{29}$ (Zhang et al., 2010).

30 (Mont, 2008).

31 (Geng et al., 2010b).

32 (Gao et al., 2006).

33 (Geng et al., 2010b).

${ }^{34}$ In the original "(...) suppose également des politiques publiques dédiées et de nouvelles formes de coopération, entre entreprises et acteurs publics."
} 
in establishing a welcoming environment for EI and entrepreneurship (for example, regarding financial instruments), as well as in providing a solid education system (thus promoting more social participation in these issues, as well as improving stakeholder confidence and long term viability), is emphasised (EMF, 2012, 2015b). For example, and illustrating the perception of the importance of a regulatory and institutional framing of a CE, the EU 2015 Action plan “(...) establishes a concrete and ambitious programme of action, with measures covering the whole cycle: from production and consumption to waste management and the market for secondary raw materials", covering not only legislative efforts but also funding tools (EC, 2015a, p. 2).

\section{Social/Cultural factors}

Finally, trends such as social sensitivity to environmental problems, shifting customer preferences (from ownership to services models), and business perception of reputational gains, are considered social drivers of a CE (Figure 5). Demand-side factors are decisive in generating momentum toward greener practices, and more sustainable choices. ${ }^{35}$

Customers' desire for, and cultural acceptance of, circular business models, including "product service systems", "performance-based contracting", "product as a service", and "servitization" (i.e. provision of a service rather than ownership), is seen as only increasing slowly, resulting in slow diffusion of CE models. Consumer habits and businesses routines are only changing very slowly because of inadequate awareness and information regarding the $\mathrm{CE}$ concept and the possible choices available. This inertia is an important barrier.

35 (Andrews and deVault, 2009; Geng et al., 2010b; Maurizio Catulli, 2012). 
In the grey literature corpus, inadequate investment in the education of consumers about circular business models is emphasised as a key gap. To address this issue, the EU refers to the need for new “(...) ways of supporting co-creation by developing, experimenting and demonstrating new business models together with end-users, taking into consideration their needs (...)" (EC, 2015b, p. 75).

\subsection{Systemic EI for a CE: An integrated assessment}

In order to map the main arguments identified, sections of the original texts were used as explanatory illustrations of the key characteristics of the two types of literature (summarised in Table 6). Overall, the CE is characterised by a "reframing" of the sustainability discussion agenda and action, focused on economic viability and appealing to governments and the private sector, through the offering of general economic benefits and business-specific solutions. Boosted by global trends related to resource volatility and ever more stringent regulatory frameworks, the CE appears nevertheless hampered by technical and institutional factors. A broad transformation is seen as contingent on more than just science and technology; i.e. a transformative change is based on a systemic approach to CE-friendly EI.

On the whole, the academic literature still seems focused on the role of technological innovation in the transition towards a CE. EI is understood as essential in overcoming "hard" technical aspects from solid wastes issues, to air pollution, water contamination and noise. ${ }^{36}$ For example, technological developments in chemistry may involve the development of nontoxic or biological materials capable of substituting oil-based plastic packaging. ${ }^{37}$ Other technological developments underscored include the capturing of waste, and the reintroduction of by-products as resources in the supply chain, thus reducing material inputs and

\footnotetext{
36 (Geng et al., 2014; Yu et al., 2014a).

37 (Grundmann et al., 2013; Matus et al., 2012; Reh, 2013; Wen et al., 2007).
} 
environmental impacts. ${ }^{38} \mathrm{EI}$ is also considered to be key for expanding the available knowledge base and promoting cooperation between actors. ${ }^{39}$ The large number of eco-industrial parks, where industrial symbiosis has been developed, underline just how crucial EI has proven to be for creating new ways of sharing services and re-utilising by-products among diverse industrial processes or actors. ${ }^{40}$ Even concerning financial barriers, transformational innovations are seen as instrumental for overcoming economic barriers, given large capital requirements and high initial costs. ${ }^{41}$ Financial innovation remains, nevertheless, a rather neglected area in innovation studies (Martin, 2016). As for addressing "soft" barriers, institutional and social innovations, encompassing the efforts of several actors (government, organisation and industries), are considered essential in a CE. ${ }^{42}$ Nevertheless, the promotion of new business models and consumer awareness of the benefits of a CE is still perceived as lacking. ${ }^{43}$ This may be related to the fact that innovation studies have often been near-sighted regarding new forms of innovation, favouring an analysis of the incumbent and most visible actors (e.g. manufacturing, high-tech, big firms, etc.) while somewhat overlooking citizens, consumers and civil society influences (Stirling, 2011). A hybrid approach to innovation, considering it to be not only led by large enterprises and public-private partnerships, but also by "grassroots" innovation movements, more centred in civil society, is scarcely addressed in science-push, top-down policy and multilateral events such as the Rio+20 (Ely et al., 2013).

\footnotetext{
38 (Chen et al., 2012; Dong et al., 2013b, 2007; Ness, 2008).

39 (Yu et al., 2014a).

40 (Chertow and Ehrenfeld, 2012; Liu et al., 2012; Mathews and Tan, 2011; Shi et al., 2010; Shi and Yu, 2014; Yu et al., 2014a).

41 (Mathews and Tan, 2011).

42 (Cerceau et al., 2014; Chen et al., 2011, 2012; Davelaar and Nijkamp, 1992; Dong et al., 2013a, 2014, 2007; Geng et al., 2010a; Langen, 2005; Liu et al., 2014; Ness, 2008; Niza et al., 2009; Patala et al., 2014; Ruiz Puente et al., 2015; van Berkel et al., 2009; Yu et al., 2014b).

43 (Albu, 2011).
} 


\section{Main arguments identified \\ CE as a multidimensional concept}

Illustration from the academic literature

"(...) circular economy does not have a single definition, it generally stresses closed flows of materials, and increased efficiency in the use of raw materials and energy." (Matus et al., 2012, p. 194)

\section{Illustration from the grey literature perspective}

"(...) the specific origins of the circular economy is a highly complex, if not impossible, task as the concept has its roots in several different schools of thought and theorie that question the prevailing linear economic systems (...)" (Rizos et al., 2015, p. 1)

“(...) many are moving towards an industrial model that decouples revenues from material input: the circular economy." (WEF, 2014, p. 14)

“(...) it is based on the principles of natural ecosystems that operate in a closed loop, minimizing energy and materials loss." (IAU, 2013, p. 13) 44

\section{EI as a transitional pathway}

“(...) what determines the 'possibility' of reuse for a material is the extent of knowledge that has led to technological innovation for reuse." (Park and Chertow, 2014, p. 47)

“(...) capacity of eco-innovations to provide new business opportunities and contribute to a transformation towards a sustainable society." (Carrillo-Hermosilla et al., 2010, p. 102) is contingent on a systems'), applying systems thinking and extending
transformative process based on systemic EI (i.e., more than just science and technology is needed for transition) the concept of product service systems, opens up many opportunities for integration and innovation, leading to much increased resource or ecoefficiency." (Ness, 2008, p. 299)

"While technological solutions form an important part of this progress, a resource efficient circular economy requires more than technological solutions alone." (Corder et al., 2015, p. 3).

"Innovative firms can create green products in response to or in anticipation of government regulation, but true green niche markets do not emerge unless there are also green consumers." (Andrews and deVault, 2009, p. 326)
Transformation “(...) viewing infrastructure as an integrated system is contingent on a to deliver services ('infrastructure service

"Systemic eco-innovation is at the heart of this paradigm shift." (EC, 2015c, p. 4)

"It aims to move societies from the extract, consume, and dispose system of today's resource use towards a more circular system of material use and re-use with less total material requirements overall." (EIO, 2012, p. 20)

"(...) the success of circular economy models will depend on adopting a systemic approach to eco-innovation that encompasses value and supply chains in their entirety and engages all actors involved in such chains." (EC, 2015b, p 73)

"(...) research and innovation are key for the EU to achieve a systemic approach to eco-innovation for a circular economy." (EC, 2015c, p. 4)

"Systemic eco-innovation requires more than science and technology. It requires new alliances, often with the engagement and the involvement of citizens, communities and municipalities building on a general environment that welcomes and is excited by innovation." (EC, 2014d, p. 19)

"(...) appropriate conditions and measures should be arranged by governments to prompt the diffusion of new sustainable goods and technologies, starting from the beginning of the transition phase." (Barbiroli, 2011, p. 25)

“(...) governmental agencies should play a leading role by coordinating different initiatives, enacting appropriate regulations (...)" (Geng et al., 2010b, p. 1507).

"Fiscal and regulatory policies have an impact in shaping the structure and processes of industrial ecosystems." (Pizzocaro, 1998, p. 231).

But established "In achieving a recycling society there is the need to continuously improve regulatory procedures so legislation is also that they do not act as impediments to successful
"The barrier of unintended consequences from existing legislation limiting circular economy opportunities is present for example in bio-refining where food safety

\footnotetext{
${ }^{44}$ In the original: "s 'inspire des principes de fonctionnement des écosystèmes naturels qui fonctionnent en boucle fermée, en minimisant les pertes d'énergie et de matières".
} 
an important

barrier and environmentally acceptable residue utilisation." (Pajunen et al., 2013, p. 154).

"Regulation could be perceived as the more

challenging barrier to overcome (...)" (Riding et

al., 2015, p. 63)

"Regulatory and bureaucratic issues are still key

obstacles (...)" (Zhu et al., 2015, p. 457).

Table 6 - Main arguments identified in the academic and grey literatures

As for the grey literature, in addition to underlining the importance of technological innovation,

it also emphasises the need for more comprehensive innovation schemes “(...) from product design to new business and market models, from new ways of turning waste into a resource to new modes of consumer behaviour" (EC, 2014a, p. 2). This literature stresses an EI approach towards the development of a $\mathrm{CE}$ sensitive to the "interaction between actors in the system (businesses, governments, knowledge institutes, social groups), institutions (rule, laws, routines) and technologies" (Bastein et al., 2013, p. 93). A more complete view of innovation, which can be labelled as "systemic", would leverage both streams of analysis, and suggest innovation trajectories rooted in inter-related developments and sectors (see Fagerberg et al., 2004). The drivers of sustainability-inducing change are many and, although this dynamic is not explicitly explored in the present paper, their interaction is non-trivial (Cecere and Martinelli, 2017). One implication is that, as Costantini et al. (2017) show, portfolio approaches to policy that take into account spillover effects from the outset, tend to generate more effective outcomes.

Particularly in EU reports, the importance of a "systemic" EI approach towards a CE is already clear. The $\mathrm{CE}$ transition is considered contingent "on adopting a systemic approach to ecoinnovation that encompasses value and supply chains in their entirety and engages all actors involved in such chains" (EC, 2015b, p. 73). The EU has, in fact, been one of the most active players in the development of a CE, directing its environmental agenda to include more circular considerations. The EU's CE agenda is nowadays part of wider efforts to make the European economy more sustainable whilst, at the same time, boosting the EU's competitiveness, creating business opportunities, jobs and opportunities for social integration and cohesion. The 
the linkages between implementing the CE and EI (EC, 2015a). In the most recent EU report, concerning progress on key initiatives of the 2015 Action Plan (EC, 2017a, 2017b), the (systemic) impact of European Commission strategy can already be seen, not only at the EU level but also at the country level. Table 7 shows an implementation of our framework using this literature.

\section{Portugal}

\begin{tabular}{|c|c|c|}
\hline Technical & $\begin{array}{l}\text { "(...) calls have also been launched in 2016, within the } \\
\text { framework of the Public Private Partnerships on } \\
\text { "Factories of the Future", "Sustainable Process Industries" } \\
\text { and "Bio-based Industries" to help develop and deploy the } \\
\text { necessary key enabling technologies to support EU } \\
\text { manufacturing across a broad range of sectors." (EC, } \\
\text { 2017b, p. 12) }\end{array}$ & $\begin{array}{l}\text { "(...) several initiatives were launched in } 2015 \\
\text { specifically targeting resource efficiency through } \\
\text { eco-innovation in industry, serving as "living labs" } \\
\text { to pilot technologies, sharing of best practices and } \\
\text { providing a platform to raise awareness on circular } \\
\text { economy and the future of the industry." (EC, } \\
\text { 2017a, p. 7) }\end{array}$ \\
\hline Economic & $\begin{array}{l}\text { "January } 2017(\ldots) \text { a platform is launched, bringing } \\
\text { together the Commission, the European Investment Bank } \\
\text { (EIB), financial market participants and businesses to } \\
\text { increase awareness of the circular economy business logic } \\
\text { and improve the uptake of circular economy projects by } \\
\text { investors." (EC, 2017b, p. 7) } \\
\text { "The Horizon } 2020 \text { Work Programme } 2016-17 \text { invests } € \\
650 \text { million in a Focus Area on "Industry } 2020 \text { in the } \\
\text { circular economy" which grants funds to demonstrate the } \\
\text { economic and environmental feasibility of the circular } \\
\text { economy approach (...)" (EC, 2017b, p. 12). }\end{array}$ & $\begin{array}{l}\text { "The support of the EU funding has significantly } \\
\text { contributed to improve the implementation of the } \\
\text { EU environmental law and policy and Portugal. } \\
\text { (...) [The "Sustainability and Efficiency in the Use } \\
\text { of Resources" (POSEUR)] aims to anticipate and } \\
\text { adapt to the global changes in the field of energy, } \\
\text { climate change and more efficient use of resources } \\
\text { (...)" (EC, 2017a, p. 25). }\end{array}$ \\
\hline Institutional & $\begin{array}{l}\text { "The actions delivered by the Commission since the } \\
\text { adoption of the Circular Economy Action Plan include } \\
\text { several legislative proposals (...) establishing an } \\
\text { ambitious long-term path leading towards waste } \\
\text { prevention and recycling" (EC, 2017b, p. 3). }\end{array}$ & $\begin{array}{l}\text { "From } 2013 \text { to } 2015 \text { several national plans were } \\
\text { revised (waste, water), placing strong emphasis on } \\
\text { efficiency and meeting EU targets in the most cost- } \\
\text { effective way, and new types of policies were } \\
\text { introduced (e.g. Green Taxation Reform). It can be } \\
\text { specially highlighted the Green Growth } \\
\text { Commitment, a national strategy adopted with the } \\
\text { purpose of reorienting the country's economic } \\
\text { development which is now focusing on the circular } \\
\text { economy." (EC, 2017a, p. 6) }\end{array}$ \\
\hline Social & $\begin{array}{l}\text { "(...) the Commission adopted a revised version of its } \\
\text { guidance on the Unfair Commercial Practices Directive } \\
\text { (...) which includes specific elements to make green } \\
\text { claims more trustworthy and transparent. (...) Misleading } \\
\text { claims can result in consumers losing confidence in labels } \\
\text { and in companies being discouraged from making truthful } \\
\text { and relevant claims, altogether hampering the circular } \\
\text { economy." (EC, 2017b, p. 9) }\end{array}$ & $\begin{array}{l}\text { "In } 2016 \text {, the Ministry of the Environment has } \\
\text { created a working group to further develop the } \\
\text { green taxation reform approved in } 2014 \text {. This work } \\
\text { should aim to deliver more incentives to green } \\
\text { behaviour (...)" (EC, 2017a, p. 24). }\end{array}$ \\
\hline
\end{tabular}

Table 7 - European Commission strategy as a driver for overcoming CE barriers - The Portuguese example as an application

The analytical challenge, however, is to grasp and direct "systems innovation" towards not only corporate but also social "circular" practices. This would be tantamount to what Schot and 
Steinmuller (2016) refer to as "transformative innovation". This "transformation turn" in innovation studies may yield a working frame to make sense of the recent discussions on the regulation of risky technologies (Bonnín Roca et al., 2017), the governance of access to emergent knowledge (Gans et al., 2017), the enhancement of inducements for up-stream innovation (stimulating the local generation of local inputs, e.g. Chakraborty and Chatterjee, 2017) and the facilitation of competitive diffusion of critical green downstream solutions (such as storage technologies, see Fabrizio et al., 2017, and Stephan et al., 2017).

As for the corporate world, although “(...) in the driver's seat in the transition to a circular economy" (EC, 2014b, p. 2), it nevertheless seems to be slow in adjusting its own business models and environmental considerations. Examples, such as Coca-Cola using renewable, plant-based materials in packaging (Coca-Cola, 2015) or Nestle/Nespresso's collecting and recycling used Nespresso capsules (EMF, 2012, 2014b, 2015a) are still exceptions. Also, both academic and grey literatures are consistent regarding warnings as to the ambiguous value of circular business models and EI's environmental credentials. Critical considerations regarding the "goodness" of innovation must guide the integral analysis of the process of transition. Innovation is not enough. Systemic, transformative, and effectively sustainable, innovation is the pre-requisite for genuine sustainability, as some pioneering examples around the world are already demonstrating (Box 1). 


\section{Box 1. EI pathway toward CE implementation: Samsø, an example of systemic EI CE}

Transition is more than focusing on unique pathways, or "silver bullets". Relevant cases such as pilot projects and demonstration markets can be interpreted as fundamental sign posts of new values and modes of organising that do not depend on single factors but rather on complex societal processes engaging many actors and sectors in holistic ways (Huguenin and Jeannerat, 2017).

The Danish island of Samsø stands as a pioneer example of a successful "green community". Samsø was, till the end of the 20th century, entirely dependent of imported oil and coal (Brandt and Svendsen, 2016). In 1997 the island won a competition to be a "Renewable Energy Island" (REI). A 10-year plan followed to develop a self-sufficient energy supply base, running on renewable energy. By 2005 wind, solar and biomass fulfilled that goal (Nielsen and Jørgensen, 2015). More recently (October 2015) Samsø launched the "Full Circle Island" project, an initiative intended to make the island the first "circular" community.

What are, therefore, the conditions that allowed those accomplishments? The success of the REI project and the island's aspirations regarding circularity has been credited to the convergence of a set of factors of different nature. The key was the systemic integration, and mutual reinforcement, of many elements.

Initially, the transition process relied on hard factors (our terminology; see Sperling, 2017). It was facilitated by technological drivers (wind turbines, district heating plants and solar thermal plants). National funding of costly infrastructures was a fundamental economic driver as well, accompanied by a variety of incentive schemes for renewable energy adoption, which succeeded in nudging household choices.

But soft factors also contributed to support the process (see Brandt and Svendsen, 2016). On the one hand, visions articulated at the national level were an institutional driver, providing clear guidelines and coherence to the project. On the other hand, local popular involvement, effective communication and a vibrant cultural context emerged as social drivers too (for another, also Nordic, case on the importance of the role of cultural resources and the social basis of ecological change see Kaltenborn et al., 2017).

\section{Conclusions}

Which factors are helping, and which factors are hindering the CE? Within the sustainability transition debate, and using an innovation studies perspective, this paper attempts to provide some insight regarding soft and hard factors, as well as the broader role of eco-innovation (EI) in the transition to a circular economy (CE). In order to provide checks and balances in the analysis, two types of literature sources were contrasted: academic (WoS and Scopus papers) and grey (reports and policy papers). The systematic review of the academic literature enabled a scientific identification of some facts, as well as the assessment of the most important CE barriers and drivers. The grey literature provided a form of "sensitivity analysis", an alternative type of content that was used to appraise the information gathered through the academic review. 
Globally, the CE was found to be driven particularly by "soft" (i.e. social, regulatory or institutional) factors. Public agencies have a crucial role in institutional framing, from infrastructures to legal set-ups, as well as in R\&D support and increasing social awareness. At the same time "hard" barriers, related to the availability of technical solutions and financial factors, can hamper expansion of the CE. Even when CE solutions are already technically feasible, their practical implementation is often limited by economic and market limitations. EI is considered to be an essential pathway for overcoming barriers to a CE transition. Although academic literature still focuses mostly on technologically-based innovation, grey literature sources (and in particular EU reports) increasingly refer to systemic innovation.

Underlining the heterogeneity of the issue, a key conclusion is that the innovation system's view should not be lost when considering the transition towards a CE. A multidimensional, multi-actor $\mathrm{CE}$ is argued for, requiring not only technological innovation but also broad institutional change in markets, public policies and social practices. As Schot and Kanger (2016, p. 25) state: reinventing “(...) the way we innovate (...)" is the key for this transition. In innovation studies of transition this novel "transformation turn" perspective paves the way to a more dynamic conceptual, empirical and policy approach to CE. This paper argues EI is a centre-piece of this emerging research program.

Regarding policy implications, institutional framing is in itself a driver, but it also carries risks for a CE. A coherent strategic roadmap is therefore essential for avoiding mismatches and contradictory incentives. The focus on the promotion of systemic EI is also of paramount importance. The challenge is, nonetheless, to direct "innovation systems" towards CE-inducing productive and social practices.

The unavoidable methodological and database limitations of this paper point to avenues for further research. First, whereas this paper adopted an interpretation-rich and hands-on approach 
to bibliographic data, other techniques (such as text mining) may be able to take this research further. Second, the CE framework requires more empirical content, so as to bring forward evidence of its actual "transformational" value (Schot and Kanger, 2016). Third, more information is required regarding heterogeneity in implementation of the $\mathrm{CE}$, so as to address interactions and linkages, as well as trade-offs and mismatches, between technological and socio-institutional systems (Stirling, 2011, p. 83). Finally, a deeper understanding is needed regarding the specific EI tools required for achieving a ("transformative" and "systemic") CE "transition". In this sense, the insights that are wired up in this paper aim to help facilitate the development of policy guidelines and organisational strategies.

\section{Acknowledgements}

This work was supported by the Portuguese Science and Technology Foundation Grant Ref: SFRH/BD/52295/2013. CENSE is financed through Strategic Project PestOE/AMB/UI4085/2013 from the Portuguese Science and Technology Foundation. This work was also supported by the Portuguese Science and Technology Foundation Grant UID/GES/00315/2013. The funding sources played no part in the design, analysis, interpretation, or writing-up of the article or in the decision to publish. We would like to thank the SWPS anonymous referees. We also benefited greatly from the journal review process and would like to extend our appreciation to the anonymous referees and the Editor, Dale S. Rothman, for their feedback. Finally, we would like to acknowledge the insightful remarks and suggestions of Paula Antunes, Tommaso Ciarli, Carlena Ficano Tim Foxon, Rui Santos and Dan Ward. The authors alone are to be blamed for the surviving shortcomings. 


\section{References}

Albu, A., 2011. Business innovation using industrial ecology. Metalurgia international 16, $28-31$.

Allwood, J.M., 2014. Chapter 30 - Squaring the Circular Economy: The Role of Recycling within a Hierarchy of Material Management Strategies, in: Worrell, E., Reuter, M.A. (Eds.), Handbook of Recycling. Elsevier, Boston, pp. 445-477.

Andersen, M.M., 2008. Eco-innovation - towards taxonomy and a theory. Presented at the Entrepreneurship and innovation - organizations, institutions, systems and regions, DRUID Conference, Copenhagen, CBS, Denmark.

Andrews, C., deVault, D., 2009. Green Niche Market Development. Journal of Industrial Ecology 13, 326-345. doi:10.1111/j.1530-9290.2009.00112.x

Ausubel, J.H., 1992. Industrial ecology: reflections on a colloquium. Proceedings of the National Academy of Sciences of the United States of America 89, 879-884.

Ayres, R.U., 1994. Industrial metabolism: Theory and Practice, in: Simonis, U.E., Ayres, R.U. (Eds.), Industrial Metabolism: Restructuring for Sustainable Development. United Nations Univ, Tokyo; New York.

Bakker, C., Wang, F., Huisman, J., den Hollander, M., 2014. Products that go round: exploring product life extension through design. Journal of Cleaner Production 69, 10-16. doi:10.1016/j.jclepro.2014.01.028

Barbiroli, G., 2011. Economic consequences of the transition process toward green and sustainable economies: costs and advantages. International Journal of Sustainable Development \& World Ecology 18, 17-27. doi:10.1080/13504509.2011.541592

Bastein, T., Roelofs, E., Rietveld, E., Hoogendoorn, A., 2013. Opportunities for a circular economy in The Netherlands. TNO.

Bergquist, A.-K., Söderholm, K., Kinneryd, H., Lindmark, M., Söderholm, P., 2013. Command-and-control revisited: Environmental compliance and technological change in Swedish industry 1970-1990. Ecological Economics, New Climate Economics 85, 6-19. doi:10.1016/j.ecolecon.2012.10.007

Bonnín Roca, J., Vaishnav, P., Morgan, M.G., Mendonça, J., Fuchs, E., 2017. When risks cannot be seen: Regulating uncertainty in emerging technologies. Research Policy 46, 1215-1233. doi:10.1016/j.respol.2017.05.010

Boons, F., Montalvo, C., Quist, J., Wagner, M., 2013. Sustainable innovation, business models and economic performance: an overview. Journal of Cleaner Production, Sustainable Innovation and Business Models 45, 1-8. doi:10.1016/j.jclepro.2012.08.013

Böttcher, C.F., Müller, M., 2013. Drivers, Practices and Outcomes of Low-carbon Operations: Approaches of German Automotive Suppliers to Cutting Carbon Emissions. Bus. Strat. Env. 477-498. doi:10.1002/bse.1832

Boulding, K.E., 1966. The Economics of the Coming Spaceship Earth, in: Jarrett, H. (Ed.), Environmental Quality in a Growing Economy: Essays from the Sixth RFF Forum. Routledge, pp. 3-15.

Brandt, U.S., Svendsen, G.T., 2016. When can a green entrepreneur manage the local environment? Journal of Environmental Management 183, Part 3, 622-629. doi:10.1016/j.jenvman.2016.09.007 
Braungart, M., McDonough, W., 2002. Cradle to Cradle: Remaking the Way We Make Things, 1st edition. ed. North Point Press, New York.

Carrillo-Hermosilla, J., del Río, P., Könnölä, T., 2010. Diversity of eco-innovations: Reflections from selected case studies. Journal of Cleaner Production 18, 1073-1083. doi:10.1016/j.jclepro.2010.02.014

Carrillo-Hermosilla, J., Gonzaléz, P. del R., Könnölä, T., 2009. Eco-Innovation: When Sustainability and Competitiveness Shake Hands. Palgrave Macmillan.

Cecere, G., Martinelli, A., 2017. Drivers of knowledge accumulation in electronic waste management: An analysis of publication data. Research Policy 46, 925-938. doi:10.1016/j.respol.2017.03.005

Cerceau, J., Mat, N., Junqua, G., Lin, L., Laforest, V., Gonzalez, C., 2014. Implementing industrial ecology in port cities: international overview of case studies and cross-case analysis. Journal of Cleaner Production 74, 1-16. doi:10.1016/j.jclepro.2014.03.050

Chakraborty, P., Chatterjee, C., 2017. Does environmental regulation indirectly induce upstream innovation? New evidence from India. Research Policy 46, 939-955. doi:10.1016/j.respol.2017.03.004

Chappin, E.J.L., Ligtvoet, A., 2014. Transition and transformation: A bibliometric analysis of two scientific networks researching socio-technical change. Renewable and Sustainable Energy Reviews 30, 715-723. doi:10.1016/j.rser.2013.11.013

Chen, X., Fujita, T., Ohnishi, S., Fujii, M., Geng, Y., 2012. The Impact of Scale, Recycling Boundary, and Type of Waste on Symbiosis and Recycling. Journal of Industrial Ecology 16, 129-141. doi:10.1111/j.1530-9290.2011.00422.x

Chen, X., Xi, F., Geng, Y., Fujita, T., 2011. The potential environmental gains from recycling waste plastics: simulation of transferring recycling and recovery technologies to Shenyang, China. Waste Manag 31, 168-179. doi:10.1016/j.wasman.2010.08.010

Chertow, M.R., Ehrenfeld, J., 2012. Organizing Self-Organizing Systems. Journal of industrial ecology 16, 13-27. doi:10.1111/j.1530-9290.2011.00450.x

Clark, J.H., Farmer, T.J., Herrero-Davila, L., Sherwood, J., 2016. Circular economy design considerations for research and process development in the chemical sciences. Green Chem. 18, 3914-3934. doi:10.1039/C6GC00501B

Coca-Cola, 2015. Coca-Cola Enterprises : News : Infineo 2.0 - The first online circular economy platform [WWW Document]. URL https://www.cokecce.com/news-andevents/news/infineo-2-0-the-first-online-circular-economy-platform (accessed 1.13.15).

Conn, W., 1978. Factors Affecting Product Lifetime: A Study in Support of Policy Development for Waste Reduction. Final Report, National Science Foundation 1-214.

Corder, G.D., Golev, A., Giurco, D., 2015. "Wealth from metal waste": Translating global knowledge on industrial ecology to metals recycling in Australia. Minerals Engineering, Sustainable Minerals 76, 2-9. doi:10.1016/j.mineng.2014.11.004

Costantini, V., Crespi, F., Palma, A., 2017. Characterizing the policy mix and its impact on eco-innovation: A patent analysis of energy-efficient technologies. Research Policy 46, 799-819. doi:10.1016/j.respol.2017.02.004

Cuerva, M.C., Triguero-Cano, Á., Córcoles, D., 2014. Drivers of green and non-green innovation: empirical evidence in Low-Tech SMEs. Journal of Cleaner Production 68, 104-113. doi:10.1016/j.jclepro.2013.10.049 
Davelaar, E.-J., Nijkamp, 1992. Operational Models on Industrial Innovation and Spatial Development. Journal of Scientific \& Industrial Research 51, 273-284.

del Río, P., Carrillo-Hermosilla, J., Könnölä, T., 2010. Policy Strategies to Promote EcoInnovation. Journal of Industrial Ecology 14, 541-557. doi:10.1111/j.15309290.2010.00259.x

Dewick, P., Foster, C., Green, K., 2007. Technological Change and the Environmental Impact of Food Production and Consumption (SSRN Scholarly Paper No. ID 1005183). Social Science Research Network, Rochester, NY.

Dong, L., Fujita, T., Zhang, H., Dai, M., Fujii, M., Ohnishi, S., Geng, Y., Liu, Z., $2013 a$. Promoting low-carbon city through industrial symbiosis: A case in China by applying HPIMO model. Energy Policy 61, 864-873. doi:10.1016/j.enpol.2013.06.084

Dong, L., Gu, F., Fujita, T., Hayashi, Y., Gao, J., 2014. Uncovering opportunity of lowcarbon city promotion with industrial system innovation: Case study on industrial symbiosis projects in China. Energy Policy 65, 388-397. doi:10.1016/j.enpol.2013.10.019

Dong, L., Zhang, H., Fujita, T., Ohnishi, S., Li, H., Fujii, M., Dong, H., 2013b. Environmental and economic gains of industrial symbiosis for Chinese iron/steel industry: Kawasaki's experience and practice in Liuzhou and Jinan. Journal of Cleaner Production 59, 226-238. doi:10.1016/j.jclepro.2013.06.048

Dong, S., Li, Z., Li, B., Xue, M., 2007. Problems and Strategies of Industrial Transformation of China's Resource-based Cities. China Population, Resources and Environment 17, 12-17. doi:10.1016/S1872-583X(08)60005-4

EC, 2017a. The EU Environmental Implementation Review Country Report - Portugal (Communication from the Commission to the European Parliament, the Council, the European Economic and Social Committee and the Committee of the Regions No. SWD(2017) 54 final), Commission staff working document accompanying the document: The EU Environmental Implementation Review: Common Challenges and how to combine efforts to deliver better results. Directorate-General for Environment, European Commission, Brussels.

EC, 2017b. Report on the implementation of the Circular Economy Action Plan (Communication from the Commission to the European Parliament, the Council, the European Economic and Social Committee and the Committee of the Regions. No. COM(2017) 33 final). European Commission, Directorate-General for the Environment.

EC, 2015a. Closing the loop - An EU action plan for the Circular Economy (Communication from the Commission to the European Parliament, the Council, the European Economic and Social Committee and the Committee of the Regions. No. $\operatorname{COM}(2015) 614$ final). European Commission, Directorate-General for the Environment.

EC, 2015b. Draft Horizon 2020 Work Programme 2016 - 2017 17. Cross-cutting activities (Focus Areas). European Commission.

EC, 2015c. From niche to norm (Suggestions by the group of experts on a "systemic approach to eco-innovation to achieve a low-carbon, circular economy"). European Commission; Directorate-General for Research and Innovation; Directorate I - Climate Action and Resource Efficiency.

EC, 2014a. Towards a circular economy: A zero waste programme for Europe (Communication from the Commission to the European Parliament, the Council, the 
European Economic and Social Committee and the Committee of the Regions.). European Commission, Directorate-General for the Environment.

EC, 2014b. The circular economy - Connecting, creating and conserving value. European Commission.

EC, 2011. Innovation for a sustainable Future - The Eco-innovation Action Plan (Eco-AP), $\operatorname{COM}(2011) 899$ final. Communication from the Commission to the European Parliament, the Council, the European Economic and Social Committee and the Committee of the Regions. European Commission.

Eckelman, M.J., Chertow, M.R., 2009. Using Material Flow Analysis to Illuminate LongTerm Waste Management Solutions in Oahu, Hawaii. Journal of Industrial Ecology 13, 758-774. doi:10.1111/j.1530-9290.2009.00159.x

EIO, 2016. Policies and Practices for Eco-Innovation Uptake and Circular Economy Transition. Eco-Innovation Observatory. Funded by the European Commission, DG Environment, Brussels.

EIO, 2013. A systemic perspective on eco-innovation. Eco-Innovation Observatory. Funded by the European Commission, DG Environment, Brussels.

EIO, 2012. Methodological Report. Eco-Innovation Observatory, Brussels.

Elsevier, 2016. Journal of Cleaner Production [WWW Document]. About this Journal. URL http://www.journals.elsevier.com/journal-of-cleaner-production (accessed 4.5.16).

Ely, A., Smith, A., Stirling, A., Leach, M., Scoones, I., 2013. Innovation Politics PostRio+20: Hybrid Pathways to Sustainability? Environ Plann C Gov Policy 31, 1063-1081. doi:10.1068/c12285j

EMF, 2015a. Growth within: A circular economy vision for a competitive Europe. Ellen MacArthur Foundation and McKinsey Center for Business and Environment.

EMF, 2015b. Delivering the Circular economy: A toolkit for policymakers. Ellen MacArthur Foundation.

EMF, 2014a. Circular Economy 100 [WWW Document]. Ellen MacArthur Foundation. URL http://www.ellenmacarthurfoundation.org/business/ce100 (accessed 8.1.14).

EMF, 2014b. Towards the Circular Economy: accelerating the scale-up across global supply chains (No. Vol. 3). Ellen MacArthur Foundation (EMF); World Economic Forum; McKinsey \& Company.

EMF, 2013. Towards the Circular Economy: opportunities for the consumer goods sector (No. Vol. 2). Ellen MacArthur Foundation (EMF).

EMF, 2012. Towards the Circular Economy: economic and business rationale for an accelerated transition (No. Vol. 1). Ellen MacArthur Foundation (EMF).

Fabrizio, K.R., Poczter, S., Zelner, B.A., 2017. Does innovation policy attract international competition? Evidence from energy storage. Research Policy 46, 1106-1117. doi:10.1016/j.respol.2017.04.003

Fagerberg, J., Mowery, D.C., Nelson, R.R., 2004. The Oxford Handbook of Innovation, New edition edition. ed. Oxford University Press, Oxford; New York.

Freeman, C., 1987. Technology Policy and Economic Performance: Lessons from Japan. Pinter Pub Ltd, London; New York. 
Frosch, R.A., 1992. Industrial ecology: a philosophical introduction. PNAS 89, 800-803. doi:10.1073/pnas.89.3.800

Frosch, R.A., Gallopoulos, N.E., 1989. Strategies for Manufacturing. Scientific American 261, 144-52.

Gans, J.S., Murray, F.E., Stern, S., 2017. Contracting over the disclosure of scientific knowledge: Intellectual property and academic publication. Research Policy 46, 820-835. doi:10.1016/j.respol.2017.02.005

Gao, C., Hou, H., Zhang, J., Zhang, H., Gong, W., 2006. Education for regional sustainable development: experiences from the education framework of HHCEPZ project. Journal of Cleaner Production 14, 994-1002. doi:10.1016/j.jclepro.2005.11.043

Geng, Y., Fu, J., Sarkis, J., Xue, B., 2012. Towards a national circular economy indicator system in China: an evaluation and critical analysis. Journal of Cleaner Production 23, 216224. doi:10.1016/j.jclepro.2011.07.005

Geng, Y., Liu, Z., Xue, B., Dong, H., Fujita, T., Chiu, A., 2014. Emergy-based assessment on industrial symbiosis: a case of Shenyang Economic and Technological Development Zone. Environmental science and pollution research 21, 13572-13587. doi:10.1007/s11356-014-3287-8

Geng, Y., Tsuyoshi, F., Chen, X., 2010a. Evaluation of innovative municipal solid waste management through urban symbiosis: a case study of Kawasaki. Journal of Cleaner Production 18, 993-1000. doi:10.1016/j.jclepro.2010.03.003

Geng, Y., Xinbei, W., Qinghua, Z., Hengxin, Z., 2010b. Regional initiatives on promoting cleaner production in China: a case of Liaoning. Journal of Cleaner Production 18, 15021508. doi:10.1016/j.jclepro.2010.06.028

Geng, Y., Zhu, Q., Doberstein, B., Fujita, T., 2009. Implementing China's circular economy concept at the regional level: A review of progress in Dalian, China. Waste Management 29, 996-1002. doi:10.1016/j.wasman.2008.06.036

George, D.A.R., Lin, B.C., Chen, Y., 2015. A circular economy model of economic growth. Environmental Modelling \& Software 73, 60-63. doi:10.1016/j.envsoft.2015.06.014

Georgesçu-Roegen, N., 1971. The entropy law and the economic process. Harvard University Press.

Ghisellini, P., Cialani, C., Ulgiati, S., 2016. A review on circular economy: the expected transition to a balanced interplay of environmental and economic systems. Journal of Cleaner Production, Towards Post Fossil Carbon Societies: Regenerative and Preventative Eco-Industrial Development 114, 11-32. doi:10.1016/j.jclepro.2015.09.007

Golini, R., Longoni, A., Cagliano, R., 2014. Developing sustainability in global manufacturing networks: The role of site competence on sustainability performance. International Journal of Production Economics, Building Supply Chain System Capabilities in the Age of Global Complexity: Emerging Theories and Practices 147, Part B, 448-459. doi:10.1016/j.ijpe.2013.06.010

Govindan, K., Kaliyan, M., Kannan, D., Haq, A.N., 2014. Barriers analysis for green supply chain management implementation in Indian industries using analytic hierarchy process. International Journal of Production Economics, Building Supply Chain System Capabilities in the Age of Global Complexity: Emerging Theories and Practices 147, Part B, 555-568. doi:10.1016/j.ijpe.2013.08.018 
Granjou, C., Walker, J., Salazar, J.F., 2017 (in press). The politics of anticipation: On knowing and governing environmental futures. Futures. doi:10.1016/j.futures.2017.05.007

Gregson, N., Crang, M., Fuller, S., Holmes, H., 2015. Interrogating the circular economy: the moral economy of resource recovery in the EU. Economy and Society 44, 218-243. doi:10.1080/03085147.2015.1013353

Greyson, J., 2007. An economic instrument for zero waste, economic growth and sustainability. Journal of Cleaner Production, Approaching zero emissions 15, 1382-1390. doi:10.1016/j.jclepro.2006.07.019

Grundmann, V., Bilitewski, B., Zehm, A., Darbra, R.M., Barceló, D., 2013. Risk-based management of chemicals and products in a circular economy at a global scale- Impacts of the FP7 funded project RISKCYCLE. Environmental Sciences Europe 25, 14. doi:10.1186/2190-4715-25-14

Gupta, S., Palsule-Desai, O.D., 2011. Sustainable supply chain management: Review and research opportunities. IIMB Management Review 23, 234-245. doi:10.1016/j.iimb.2011.09.002

Heyes, A., Kapur, S., 2011. Regulatory attitudes and environmental innovation in a model combining internal and external R\&D. Journal of Environmental Economics and Management 61, 327-340. doi:10.1016/j.jeem.2010.12.003

Hobson, K., Lynch, N., 2016. Diversifying and de-growing the circular economy: Radical social transformation in a resource-scarce world. Futures 82, 15-25. doi:10.1016/j.futures.2016.05.012

Huesemann, M.H., Huesemann, J.A., 2007. Will progress in science and technology avert or accelerate global collapse? A critical analysis and policy recommendations. Environ Dev Sustain 10, 787-825. doi:10.1007/s10668-007-9085-4

Huguenin, A., Jeannerat, H., 2017. Creating change through pilot and demonstration projects: Towards a valuation policy approach. Research Policy 46, 624-635. doi:10.1016/j.respol.2017.01.008

IAU, 2013. Économie circulaire, écologie industrielle Éléments de réflexion à l'échelle de l'Île-de-Franc. L'Institut d'aménagement et d'urbanisme de la région d'Île-de-France.

Ilić, M., Nikolić, M., 2016. Drivers for development of circular economy - A case study of Serbia. Habitat International 56, 191-200. doi:10.1016/j.habitatint.2016.06.003

Ji, G., Gunasekaran, A., Yang, G., 2014. Constructing sustainable supply chain under double environmental medium regulations. International Journal of Production Economics, Building Supply Chain System Capabilities in the Age of Global Complexity: Emerging Theories and Practices 147, Part B, 211-219. doi:10.1016/j.ijpe.2013.04.012

Johnson, M.W., Suskewicz, J., 2009. How to Jump-Start the Clean-Tech Economy. Harvard Business Review.

Jones, P.T., Geysen, D., Tielemans, Y., Van Passel, S., Pontikes, Y., Blanpain, B., Quaghebeur, M., Hoekstra, N., 2013. Enhanced Landfill Mining in view of multiple resource recovery: a critical review. Journal of Cleaner Production 55, 45-55. doi:10.1016/j.jclepro.2012.05.021

Kaenzig, J., Wüstenhagen, R., 2010. The Effect of Life Cycle Cost Information on Consumer Investment Decisions Regarding Eco-Innovation. Journal of Industrial Ecology 14, 121-136. doi:10.1111/j.1530-9290.2009.00195. 
Kaltenborn, B.P., Krange, O., Tangeland, T., 2017. Cultural resources and public trust shape attitudes toward climate change and preferred futures-A case study among the Norwegian public. Futures 89, 1-13. doi:10.1016/j.futures.2017.04.005

Kemp, R., 2010. Eco-innovation: Definition, Measurement and Open Research Issues. Economia politica 397-420.

Köhler, A.R., Hilty, L.M., Bakker, C., 2011. Prospective Impacts of Electronic Textiles on Recycling and Disposal. Journal of Industrial Ecology 15, 496-511. doi:10.1111/j.15309290.2011.00358.x

Kunapatarawong, R., Martínez-Ros, E., 2016. Towards green growth: How does green innovation affect employment? Research Policy 45, 1218-1232. doi:10.1016/j.respol.2016.03.013

Langen, P.W. de, 2005. Trends and Opportunities for the Long-Term Development of Rotterdam Port Complex. Coastal Management 33, 215-224. doi:10.1080/08920750590919691

Levänen, J., 2015. Ending waste by law: institutions and collective learning in the development of industrial recycling in Finland. Journal of Cleaner Production 87, 542-549. doi:10.1016/j.jclepro.2014.09.085

Li, N., Zhang, T., Liang, S., 2013. Reutilisation-extended material flows and circular economy in China. Waste Management 33, 1552-1560. doi:10.1016/j.wasman.2013.01.029

Lin, B.C., Zheng, S., 2016. A New Direction in Environmental Economics. Journal of Economic Surveys 30, 397-402. doi:10.1111/joes.12166

Linnenluecke, M.K., Griffiths, A., 2013. Firms and sustainability: Mapping the intellectual origins and structure of the corporate sustainability field. Global Environmental Change 23, 382-391. doi:10.1016/j.gloenvcha.2012.07.007

Liu, D., Li, H., Wang, W., Dong, Y., 2012. Constructivism scenario evolutionary analysis of zero emission regional planning: A case of Qaidam Circular Economy Pilot Area in China. International Journal of Production Economics 140, 341-356. doi:10.1016/j.ijpe.2011.04.008

Liu, H., Zhou, G., Wennersten, R., Frostell, B., 2014. Analysis of sustainable urban development approaches in China. Habitat International 41, 24-32. doi:10.1016/j.habitatint.2013.06.005

Liu, Y., 2009. Investigating external environmental pressure on firms and their behavior in Yangtze River Delta of China. Journal of Cleaner Production 17, 1480-1486. doi:10.1016/j.jclepro.2009.05.010

Liu, Y., Bai, Y., 2014. An exploration of firms' awareness and behavior of developing circular economy: An empirical research in China. Resources, Conservation and Recycling 87, 145-152. doi:10.1016/j.resconrec.2014.04.002

Lombardi, D.R., Laybourn, P., 2012. Redefining Industrial Symbiosis. Journal of Industrial Ecology 16, 28-37. doi:10.1111/j.1530-9290.2011.00444.x

Lowy, A., Hood, P., 2004. The Power of the 2 x 2 Matrix: Using 2 x 2 Thinking to Solve Business Problems and Make Better Decisions. John Wiley \& Sons.

Lund, R.T., 1985. Remanufacturing: the experience of the United States and implications for developing countries (World Bank Technical Paper No. 31). The World Bank. 
Lund, R.T., Skeels, F.D., 1983. Start-up Guidelines for the Independent Remanufacturer. Massachusetts Institute of Technology.

Markard, J., Raven, R., Truffer, B., 2012. Sustainability transitions: An emerging field of research and its prospects. Research Policy, Special Section on Sustainability Transitions 41, 955-967. doi:10.1016/j.respol.2012.02.013

Martin, B.R., 2016. Twenty challenges for innovation studies. Science and Public Policy 43, 432-450. doi:10.1093/scipol/scv077

Mathews, J.A., Tan, H., 2011. Progress Toward a Circular Economy in China. Journal of Industrial Ecology 15, 435-457. doi:10.1111/j.1530-9290.2011.00332.x

Matus, K.J.M., Xiao, X., Zimmerman, J.B., 2012. Green chemistry and green engineering in China: drivers, policies and barriers to innovation. Journal of Cleaner Production 32, 193-203. doi:10.1016/j.jclepro.2012.03.033

Maurizio Catulli, E.F., 2012. Information and Communication Technology-Enabled Low Carbon Technologies A New Subsector of the Economy? Journal of Industrial Ecology - J IND ECOL 16. doi:10.1111/j.1530-9290.2011.00452.x

Mendonça, S., 2014. National adaptive advantages. Soft innovation and marketing capabilities in periods of crisis and change, in: Teixeira, A.A.C., Silva, E., Mamede, R. (Eds.), Structural Change, Competitiveness and Industrial Policy: Painful Lessons from the European Periphery. Routledge, London; New York, pp. 133-151.

Michels, C., Fu, J.-Y., 2014. Systematic analysis of coverage and usage of conference proceedings in web of science. Scientometrics 100, 307-327. doi:10.1007/s11192-014$1309-4$

Mirhedayatian, S.M., Azadi, M., Farzipoor Saen, R., 2014. A novel network data envelopment analysis model for evaluating green supply chain management. International Journal of Production Economics, Building Supply Chain System Capabilities in the Age of Global Complexity: Emerging Theories and Practices 147, Part B, 544-554. doi:10.1016/j.ijpe.2013.02.009

Mont, O., 2008. Innovative approaches to optimising design and use of durable consumer goods. International Journal of Product Development - Int J Prod Dev 6. doi:10.1504/IJPD.2008.020395

Naveh, Z., 1998. Ecological and Cultural Landscape Restoration and the Cultural Evolution towards a Post-Industrial Symbiosis between Human Society and Nature. Restoration Ecology 6, 135-143. doi:10.1111/j.1526-100X.1998.00624.x

Ness, D., 2008. Sustainable urban infrastructure in China: Towards a Factor 10 improvement in resource productivity through integrated infrastructure systems. International journal of sustainable development and world ecology 15, 288-301. doi:10.3843/SusDev.15.4:2

Nguyen, Q.C., Ye, F., 2015. Study and evaluation on sustainable industrial development in the Mekong Delta of Vietnam. Journal of Cleaner Production. doi:10.1016/j.jclepro.2014.08.087

Nielsen, S.N., Jørgensen, S.E., 2015. Sustainability analysis of a society based on exergy studies - a case study of the island of Sams $\varnothing$ (Denmark). Journal of Cleaner Production, Integrating Cleaner Production into Sustainability Strategies 96, 12-29. doi:10.1016/j.jclepro.2014.08.035 
Niza, S., Rosado, L., Ferrão, P., 2009. Urban Metabolism. Journal of Industrial Ecology 13, 384-405. doi:10.1111/j.1530-9290.2009.00130.x

Nye, J., 1990. Soft Power. Foreign Policy 153-171. doi:10.2307/1148580

Nye, J., 2006. Think Again: Soft Power. Foreign Policy. 2006, Accessed 2017-04-19, https://foreignpolicy.com/2006/02/23/think-again-soft-power/.

OECD, 2008. Promoting sustainable consumption: good practices in OECD countries (Text). Organisation for Economic Co-operation and Development (OECD).

OECD, 1982. Product durability and product life extension: their contribution to solid waste management. Organisation for Economic Co-operation and Development.

Pajunen, N., Watkins, G., Husgafvel, R., Heiskanen, K., Dahl, O., 2013. The challenge to overcome institutional barriers in the development of industrial residue based novel symbiosis products - Experiences from Finnish process industry. Minerals Engineering 46-47, 144-156. doi:10.1016/j.mineng.2013.03.008

Paquin, R.L., Howard-Grenville, J., 2012. The Evolution of Facilitated Industrial Symbiosis. Journal of Industrial Ecology 16, 83-93. doi:10.1111/j.15309290.2011.00437.x

Park, J.Y., Chertow, M.R., 2014. Establishing and testing the "reuse potential" indicator for managing wastes as resources. Journal of Environmental Management 137, 45-53. doi:10.1016/j.jenvman.2013.11.053

Patala, S., Hämäläinen, S., Jalkala, A., Pesonen, H.-L., 2014. Towards a broader perspective on the forms of eco-industrial networks. Journal of Cleaner Production 82, 166-178. doi:10.1016/j.jclepro.2014.06.059

Pearce, D.W., Turner, R.K., 1990. Economics of natural resources and the environment. Harvester Wheatsheaf.

Pizzocaro, S., 1998. Steps to industrial ecology: reflections on theoretical aspects. International Journal of Sustainable Development \& World Ecology 5, 229-237. doi:10.1080/13504509809469988

Porter, M.E., Linde, C. van der, 1995. Toward a New Conception of the EnvironmentCompetitiveness Relationship. Journal of Economic Perspectives 9, 97-118. doi:10.1257/jep.9.4.97

Preston, F., 2012. Briefing paper - A Global Redesign? Shaping the Circular Economy. Energy, Environment and Resource Governance.

Rashid, A., Asif, F.M.A., Krajnik, P., Nicolescu, C.M., 2013. Resource Conservative Manufacturing: an essential change in business and technology paradigm for sustainable manufacturing. Journal of Cleaner Production 57, 166-177. doi:10.1016/j.jclepro.2013.06.012

Reh, L., 2013. Process engineering in circular economy. Particuology, Measurement Technology for Particulate System 11, 119-133. doi:10.1016/j.partic.2012.11.001

Rennings, K., 2000. Redefining innovation - eco-innovation research and the contribution from ecological economics. Ecological Economics 32, 319-332. doi:10.1016/S09218009(99)00112-3

Riding, M.J., Herbert, B.M.J., Ricketts, L., Dodd, I., Ostle, N., Semple, K.T., 2015. Harmonising conflicts between science, regulation, perception and environmental impact: 
The case of soil conditioners from bioenergy. Environment International 75, 52-67. doi:10.1016/j.envint.2014.10.025

Rizos, V., Behrens, A., Kafyeke, T., Hirschnitz-Garbers, M., Ioannou, A., 2015. The Circular Economy: Barriers and Opportunities for SMEs (No. 412), CEPS Working Document. Centre for European Policy Studies (CEPS).

Ruiz Puente, M.C., Arozamena, E.R., Evans, S., 2015. Industrial symbiosis opportunities for small and medium sized enterprises: preliminary study in the Besaya region (Cantabria, Northern Spain). Journal of Cleaner Production 87, 357-374. doi:10.1016/j.jclepro.2014.10.046

Sanyé-Mengual, E., Pérez-López, P., González-García, S., Lozano, R.G., Feijoo, G., Moreira, M.T., Gabarrell, X., Rieradevall, J., 2014. Eco-Designing the Use Phase of Products in Sustainable Manufacturing. Journal of Industrial Ecology 18, 545-557. doi:10.1111/jiec. 12161

Schöpfel, J., 2010. Towards a Prague Definition of Grey Literature. Presented at the Twelfth International Conference on Grey Literature: Transparency in Grey Literature. Grey Tech Approaches to High Tech Issues. Prague, 6-7 December 2010, Prague, Czech Republic, pp. 11-26.

Schot, J., Kanger, L., 2016. Deep Transitions: Emergence, Acceleration, Stabilization and Directionality (SPRU Working Paper Series No. 2016-15). SPRU - Science and Technology Policy Research, University of Sussex.

Schot, J., Steinmueller, E., 2016. Framing innovation policy for transformative change: innovation policy 3.0. Working paper series- Science Policy Research Unit (SPRU) University of Sussex.

Shi, H., Chertow, M.R., Song, Y., 2010. Developing country experience with eco-industrial parks: a case study of the Tianjin Economic-Technological Development Area in China. Journal of Cleaner Production 18, 191-199. doi:10.1016/j.jclepro.2009.10.002

Shi, L., Yu, B., 2014. Eco-Industrial Parks from Strategic Niches to Development Mainstream: The Cases of China. Sustainability 6, 6325-6331. doi:10.3390/su6096325

Skea, J., 1994. Environmental issues and innovation, in: Dodgson, M., Rothwell, R. (Eds.), The Handbook of Industrial Innovation. Edward Elgar Publishing, pp. 421-431.

Sperling, K., 2017. How does a pioneer community energy project succeed in practice? The case of the Sams $\varnothing$ Renewable Energy Island. Renewable and Sustainable Energy Reviews 71, 884-897. doi:10.1016/j.rser.2016.12.116

Stahel, W.R., 1997. The Functional Economy: Cultural and Organizational Change, in: Richards, D.J. (Ed.), The Industrial Green Game: Implications for Environmental Design and Management. Washington, DC, pp. 91-100.

Stahel, W.R., 1986. Product life as a variable: the notion of utilization. Science and Public Policy 13, 185-193. doi:10.1093/spp/13.4.185

Stahel, W.R., 1982. Product-Life Factor, in: Mitchell Prize Winning Paper 1982.

Stahel, W.R., Reday-Mulvey, G., 1981. Jobs for tomorrow: the potential for substituting manpower for energy. Vantage Press, New York,.

Standing Committee of the National People's Congress - China, 2009. Circular Economy Promotion Law of the People's Republic of China. 
Stephan, A., Schmidt, T.S., Bening, C.R., Hoffmann, V.H., 2017. The sectoral configuration of technological innovation systems: Patterns of knowledge development and diffusion in the lithium-ion battery technology in Japan. Research Policy 46, 709-723. doi:10.1016/j.respol.2017.01.009

Stirling, A., 2011. Pluralising progress: From integrative transitions to transformative diversity. Environmental Innovation and Societal Transitions 1, 82-88. doi:10.1016/j.eist.2011.03.005

Stoneman, P., 2010. Soft Innovation Economics, Product Aesthetics, and the Creative Industries, First Edition. ed. Oxford University Press, United States.

Stoneman, P., 2009. Soft innovation. Towards a more complete picture of innovative change (NESTA Research report). National Endowment for Science, Technology and the Arts (NESTA), London.

Su, B., Heshmati, A., Geng, Y., Yu, X., 2013. A review of the circular economy in China: moving from rhetoric to implementation. Journal of Cleaner Production 42, 215-227. doi:10.1016/j.jclepro.2012.11.020

Subhadra, B.G., 2011. Macro-level integrated renewable energy production schemes for sustainable development. Energy Policy 39, 2193-2196. doi:10.1016/j.enpol.2011.02.019

Tong, X., Yan, L., 2013. From Legal Transplants to Sustainable Transition. Journal of Industrial Ecology 17, 199-212. doi:10.1111/jiec.12013

Tukker, A., 2013. Product services for a resource-efficient and circular economy - a review. Journal of Cleaner Production. doi:10.1016/j.jclepro.2013.11.049

UN Statistics division, 2013. Standard Country or Area Codes for Statistical Use.

UNDESA, 2011. World Economic and Social Survey 2011 - The Great Green Technological Transformation. United Nations Department of Economic and Social Affairs, New York.

UNEP, 2006. Circular Economy: An alternative model for economic development. United Nations Environment Programme.

van Berkel, R., Fujita, T., Hashimoto, S., Geng, Y., 2009. Industrial and urban symbiosis in Japan: Analysis of the Eco-Town program 1997-2006. Journal of Environmental Management 90, 1544-1556. doi:10.1016/j.jenvman.2008.11.010

Vanner, R., Bicket, M., Withana, S., ten Brink, P., Razzini, P., van Dijl, E., Watkins, E., Hestin, M., Tan, A., Guilcher, S., Hudson, C., 2014. Scoping study to identify potential circular economy actions, priority sectors, material flows \& value chains (DG Environment's Framework contract for economic analysis ENV.F.1/FRA/2010/0044 No. Final report). Policy Studies Institute (PSI), Institute for European Environmental Policy (IEEP), BIO and Ecologic Institute.

Vernay, A.-L., Mulder, K.F., Kamp, L.M., de Bruijn, H., 2013. Exploring the sociotechnical dynamics of systems integration - the case of sewage gas for transport in Stockholm, Sweden. Journal of Cleaner Production 44, 190-199. doi:10.1016/j.jclepro.2012.11.040

Vivanco, D., Kemp, R., van der Voet, E., Heijungs, R., 2014. Using LCA-based Decomposition Analysis to Study the Multidimensional Contribution of Technological Innovation to Environmental Pressures. Journal of Industrial Ecology 18, 380-392. doi:10.1111/jiec. 12118 
Watkins, G., Husgafvel, R., Pajunen, N., Dahl, O., Heiskanen, K., 2013. Overcoming institutional barriers in the development of novel process industry residue based symbiosis products - Case study at the EU level. Minerals Engineering 41, 31-40. doi:10.1016/j.mineng.2012.10.003

WEF, 2014. Towards the Circular Economy: Accelerating the scale-up across global supply chains.

Wen, C.F., Zhao, Y.L., Liang, R.Z., 2007. Recycle of low chemical potential substance. Resources, Conservation and Recycling 51, 475-486. doi:10.1016/j.resconrec.2006.10.011

Wildschut, D., 2017 (in press). The need for citizen science in the transition to a sustainable peer-to-peer-society. Futures. doi:10.1016/j.futures.2016.11.010

Womack, J.P., Roos, D., Jones, D., 1990. The Machine That Changed the World. Scribner, New York.

Ying, J., Li-jun, Z., 2012. Study on Green Supply Chain Management Based on Circular Economy. Physics Procedia, International Conference on Solid State Devices and Materials Science, April 1-2, 2012, Macao 25, 1682-1688. doi:10.1016/j.phpro.2012.03.295

Yu, C., de Jong, M., Dijkema, G.P.J., 2014a. Process analysis of eco-industrial park development - the case of Tianjin, China. Journal of Cleaner Production 64, 464-477. doi:10.1016/j.jclepro.2013.09.002

Yu, C., de Jong, M., Dijkema, G.P.J., 2014b. Process analysis of eco-industrial park development - the case of Tianjin, China. Journal of Cleaner Production 64, 464-477. doi:10.1016/j.jclepro.2013.09.002

Yu, F., Han, F., Cui, Z., 2015. Evolution of industrial symbiosis in an eco-industrial park in China. Journal of Cleaner Production 87, 339-347. doi:10.1016/j.jclepro.2014.10.058

Zhang, L., Yuan, Z., Bi, J., Zhang, B., Liu, B., 2010. Eco-industrial parks: national pilot practices in China. Journal of Cleaner Production 18, 504-509. doi:10.1016/j.jclepro.2009.11.018

Zhu, Q., Geng, Y., 2013. Drivers and barriers of extended supply chain practices for energy saving and emission reduction among Chinese manufacturers. Journal of Cleaner Production 40, 6-12. doi:10.1016/j.jclepro.2010.09.017

Zhu, Q., Geng, Y., Sarkis, J., Lai, K.-H., 2015. Barriers to Promoting Eco-Industrial Parks Development in China. Journal of Industrial Ecology 19, 457-467. doi:10.1111/jiec.12176 


\section{Recent papers in the SPRU Working Paper Series:}

\section{September}

Towards a Typology of Intermediaries in Transitions: A Systematic Review. Paula

Kivimaa, Wouter Boon, Sampsa Hyysalo and Laurens Klerkx

\section{August}

Innovation, Inequality and the Skill Premium. Riccardo Leoncini

User-Intermediaries and the Local Embedding of Low Carbon Technologies. Jake Barnes

July

Who Gains from High-Tech Growth? High-Technology Multipliers, Employment and Wages in Britain. Neil Lee and Stephen Clarke

June

Measures, Drivers and Effects of Green Employment: Evidence from US Local Labor Markets, 2006-2014. Francesco Vona, Giovanni Marin and Davide Consoli

Structural Changes and Growth Regimes. Tommaso Ciarli, André Lorentz, Marco Valente and Maria Savona

Explaining Sociotechnical Transitions: A Critical Realist Perspective. Steve Sorrell

Social Innovation, Democracy and Makerspaces. Adrian Smith

Adoption and Diffusion of Micro-Grids in Italy. An Analysis of Regional Factors Using Agent-Based Modelling. Francesco Pasimeni

\section{May}

The Measurement of Synergy in Innovation Systems: Redundancy Generation in a Triple Helix of University-Industry-Government Relations. Loet Leydesdorff, Henry Etzkowitz, Inga Ivanova and Martin Meyer

\section{March}

Inclusive Innovation and Rapid Sociotechnical Transitions: The Case of Mobile Money in Kenya. Elsie Onsongo and Johan Schot

\section{Suggested citation:}

Ana de Jesus and Sandro Mendonça (2017). Lost in Transition? Drivers and Barriers in the Eco-innovation Road to the Circular Economy. SPRU Working Paper Series (SWPS), 1718: 1-47. ISSN 2057-6668. Available at: www.sussex.ac.uk/spru/swps 1718

\section{SPRU - Science Policy Research Unit}

University of Sussex

Falmer, Brighton, BN1 9SL,United Kingdom

SWPS Website: www.sussex.ac.uk/spru/research/swps

SPRU Website: www.sussex.ac.uk/spru

SPRU Twitter: @SPRU 